\section{Viki Jakaša Borić}

Viki Jakaša Borić

Ministarstvo kulture i medija Konzervatorski odjel u Zagrebu vjakasa@gmail.com

Izvorni znanstveni rad / Original scientific paper

Primljen / Received: 2. 6. 2021

UDK 728.81(497.5 Kerestinec)"15/18" DOI: https://doi.org/10.17018/portal.2021.5

\title{
Dvorac Erdödy u Kerestincu - renesansni kaštel 16. stoljeća i njegove mijene
}

SAžETAK: Rad donosi prikaz građevne povijesti dvorca Erdödy u Kerestincu temeljen na terenskom i arhivskom istraživanju. Analiziraju se i kontekstualiziraju njegovi građevni slojevi i mijene, od prvotne izgradnje koja se pripisuje kuriji Petra Herešnca, te nizinskog kaštela sa četiri ugaone kule koji podiže Petar III Erdödy tijekom sedamdesetih i osamdesetih godina 16. stoljeća, do obimnih barokizacijskih zahvata 18. stoljeća, pregradnji i neostilske obnove koje su uslijedile nakon velikog potresa 1880., kao i promjena kojima se tijekom 20. stoljeća oblikuje današnja situacija. Osim istraživanja in situ te analize povijesnih kartografskih izvora i fotodokumentacije Ivana Standla, velik je doprinos poznavanju prostorne strukture barokiziranog dvorca, naročito vrsta stambenih, gospodarskih i poslovnih prostorija, konstrukcija i materijala, kao i njihova interijerskog uređenja, do sada nepoznat, detaljan opis dvorca iz inventara dobra Kerestinec, sastavljen 1847. godine. Opisi i komentari vizitatora, nastali prilikom pregleda župe Sveta Nedelja tijekom 18. i 19. stoljeća, također su dragocjen izvor iz kojeg se, osim pojedinosti o izgledu i opremi dvorske kapele, saznaje da je bila posvećena Blaženoj Djevici Mariji od Navještenja te da je bila izgrađena za grofa Ladislava Erdödyja od Monyorókeréka, a blagoslovljena od biskupa Branjuga biskup Branjuga 1735. godine. Nadalje, ovim se radom preciznije utvrđuje slijed vlasništva, pri čemu posebice treba izdvojiti 1852. godinu kada prodajom dvorca završava vlasništvo Erdödyjevih u Kerestincu.

KLJUČNE RIJEČI: Kerestinec, 16., 18. i 19. stoljeće, dvorac, renesansni kaštel, barokizacija, neostilska obnova, obitelj Herešinec, obitelj Erdödy, obitelj Pallavicini, obitelj Türk
$\mathrm{S}$ mješten na rubu naselja Kerestinec, u ravničarskom krajoliku kojim protječe rječica Bernica, dvorac Erdödy (poznatiji kao Kerestinec) i danas je markantan primjer nizinskog dvorca iz razdoblja osmanskih ratova (sl. 1). Unatoč brojnim pregradnjama i slojevitosti, koja je njegovo značajno obilježje, dvorac baštini karakter kasnorenesansnog kaštela s ugaonim kulama i unutarnjim pravokutnim dvorištem (sl. 2 a i b). Osim arhitektonskih obilježja, tomu doprinosi njegov položaj na blago povišenom platou okruženom obrambenim jarcima koji su se nekada punili vodom iz Bernice i Korenjaka. Iako je stari most s lancima, koji je sa sjeverne strane vodio do glavnog ulaza $\mathrm{u}$ dvorac, zamijenjen zidanim mostom $\mathrm{s}$ kraja 19. stoljeća, sačuvana je osnovna koncepcija prilaza dvorcu preko jarka, što zajedno s konfiguracijom terena čini značajan doprinos karakteru cjeline.

Povijest vlasništva velikim je dijelom poznata iz stručne literature, pri čemu treba istaknuti tekst Emilija Laszowskog iz 1897. godine posvećen starom gradu Okiću i obitelji Erdödy, iz kojeg se saznaje da nakon napuštanja 


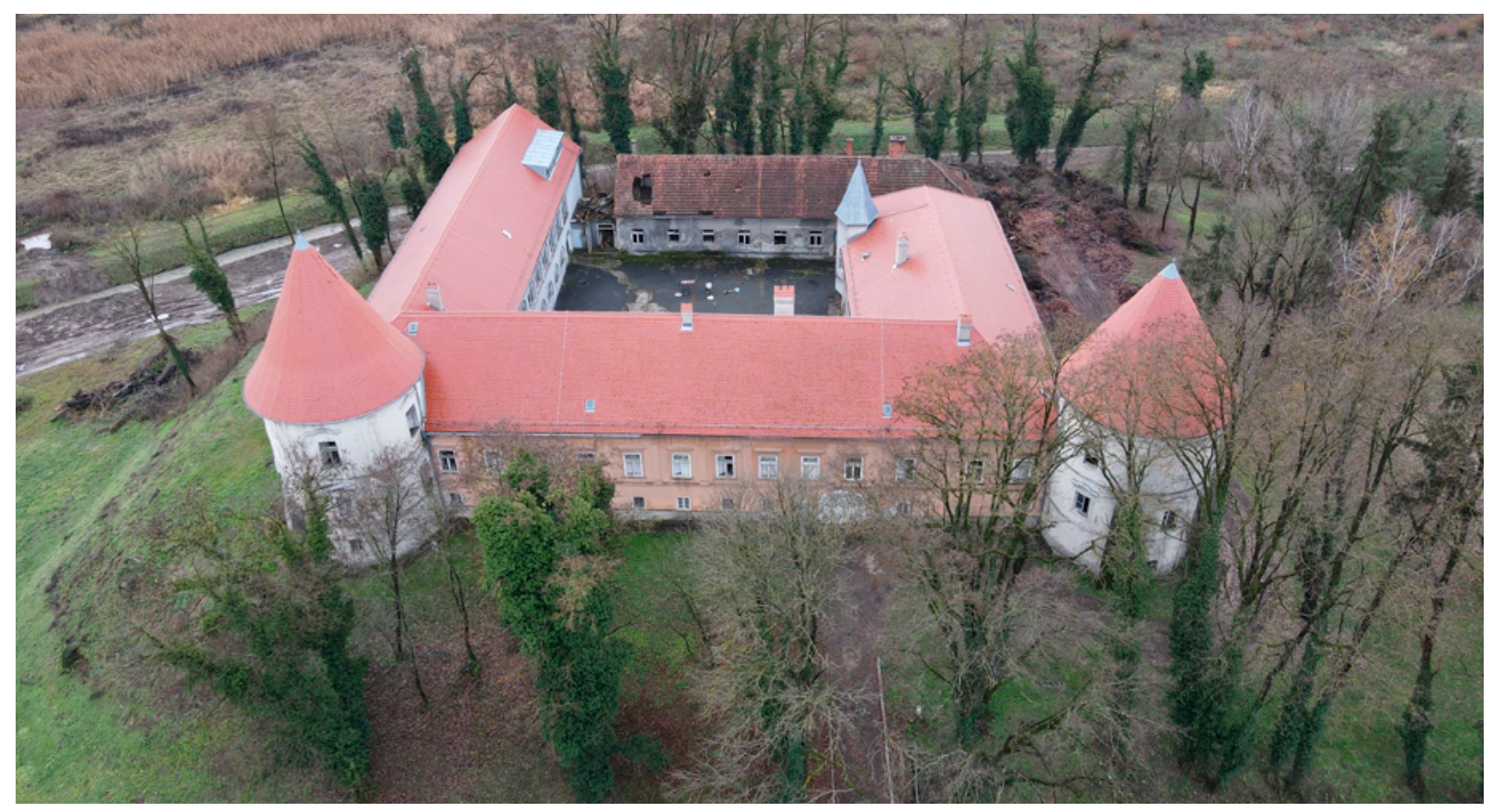

1. Zračna snimka dvorca Kerestinec (snimka: V. Madiraca, 2020.)

Aerial photo of Kerestinec castle (V. Madiraca, 2020)
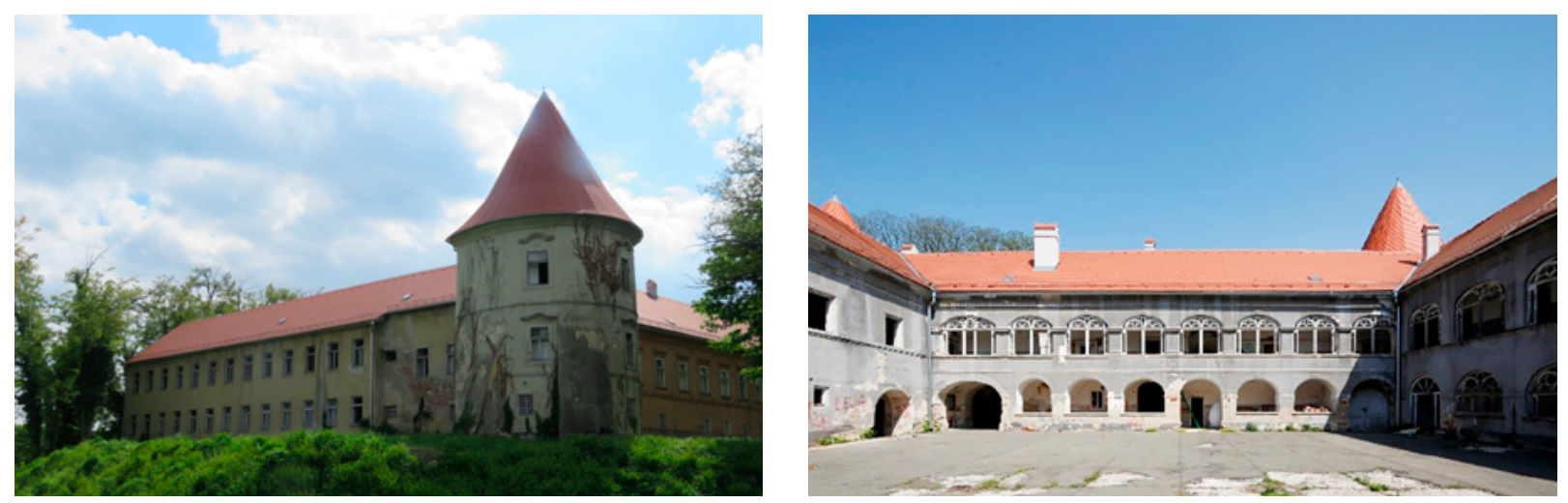

2. a - b Dvorac Kerestinec, pogled na sjeveroistočnu kulu, dvorišno pročelje sjevernog krila (snimka: V. Jakaša Borić, 2020.) Kerestinec castle, view of the northeast tower, courtyard façade of the north wing (V. Jakaša Borić, 2020)

svog okićkog obitavališta Petar Erdödy, kapetan žumberačkih uskoka, oko 1575. godine gradi „novi i veliki grad, koji opasa kulama i bedemom“. ${ }^{1}$ Prema Laszowskom od tada obitelj u potpunosti napušta Okić i živi u „udobnom novom Kerestincu“ o čemu svjedoče „mnoga tamo izdana pisma“. ${ }^{2}$ Također se saznaje da Erdödyjevi ostaju u vlasništvu dvorca do 19. stoljeća, kada ga preuzima obitelj Pallavicini, te da dvorac potkraj 19. stoljeća dolazi u ruke g. Aurela pl. Türka. ${ }^{3}$ Dragutin Feletar, pišući o povijesti Svete Nedelje i svetonedeljskog kraja, donosi nekolicinu zanimljivih podataka o izgradnji dvorca/utvrde Erdödy u Kerestincu potkraj 16. stoljeća. ${ }^{4}$ Drago Miletić ga opisuje kao nizinski dvorac s "brojnim utvrdnim elementima", dok Dubravka Botica u eseju posvećenom njegovoj neizvjesnoj budućnosti, temeljem postojećih arhitektonsko-oblikovnih obilježja, ukazuje na transformaciju od utvrde do dvorca. ${ }^{6}$ Istraživači se, naime, nisu sustavnije bavili poviješću i građevnim razvojem dvorca u Kerestincu pa je cilj provedenog terenskog i arhivskog istraživanja bio doprinijeti poznavanju njegovih građevnih slojeva $\mathrm{s}$ ciljem valorizacije cjeline i njezinih dijelova, odnosno izrade konzervatorskih smjernica za obnovu. ${ }^{7}$

Istraživanjem dvorca in situ utvrđeni su najstariji dijelovi renesansnog kaštela iz 16. stoljeća, barokizacijski sloj vezan uz zahvate kojima je tijekom prve polovice 18 . stoljeća prilagođavan novim okolnostima i načinu življenja, kao i elementi neostilske obnove koja je uslijedila nakon potresa 1880. godine. Treba istaknuti da je $u$ velikoj obnovi nakon potresa uklonjen značajan dio dvorca - dvije južne kule te gornji katovi sjevernog i zapadnog krila, a kasnije istočno i južno krilo - zbog čega provedeno istraživanje nije moglo biti sveobuhvatno, a dio 


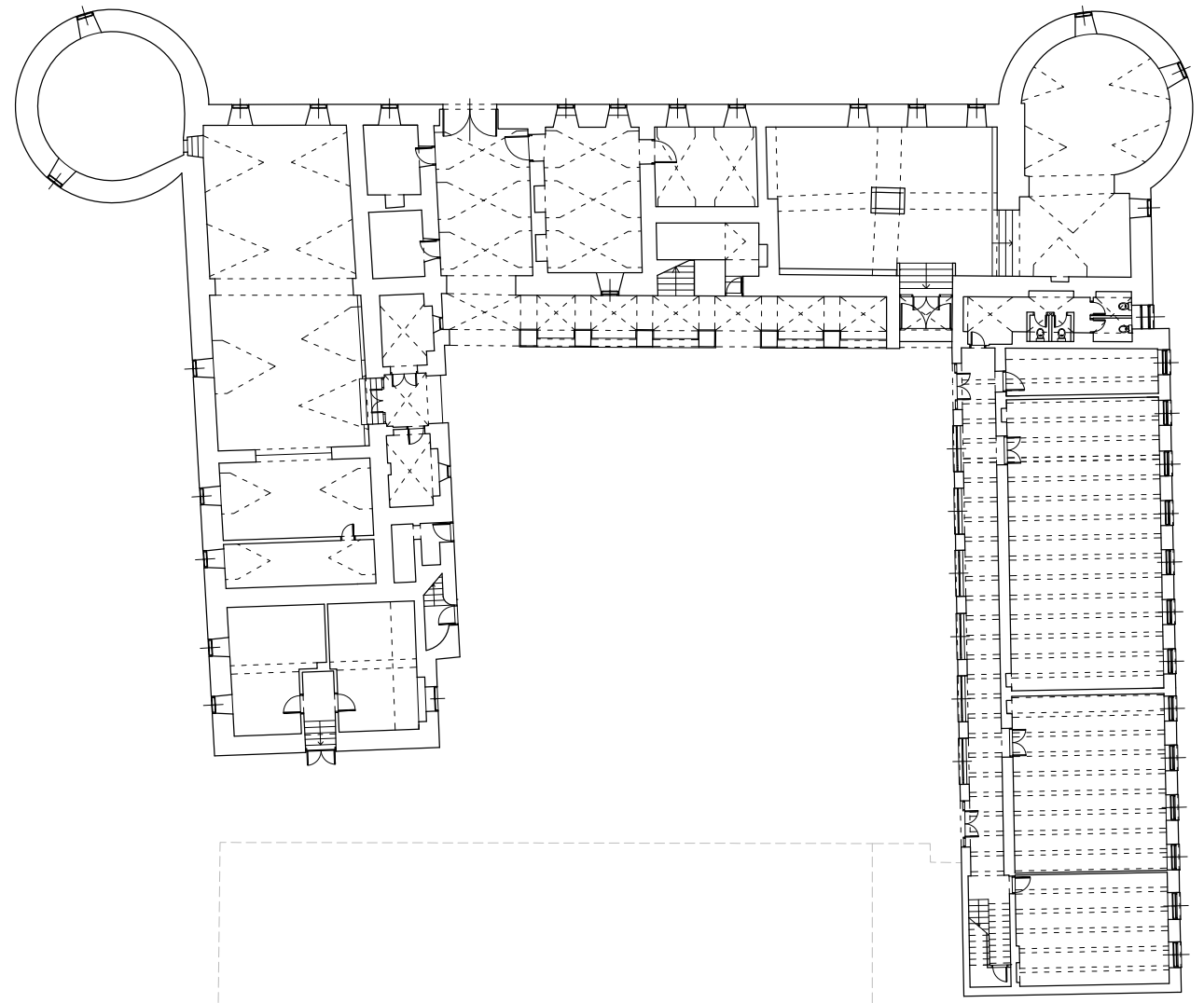

TLOCRT PRIZEMLJA M-1:200

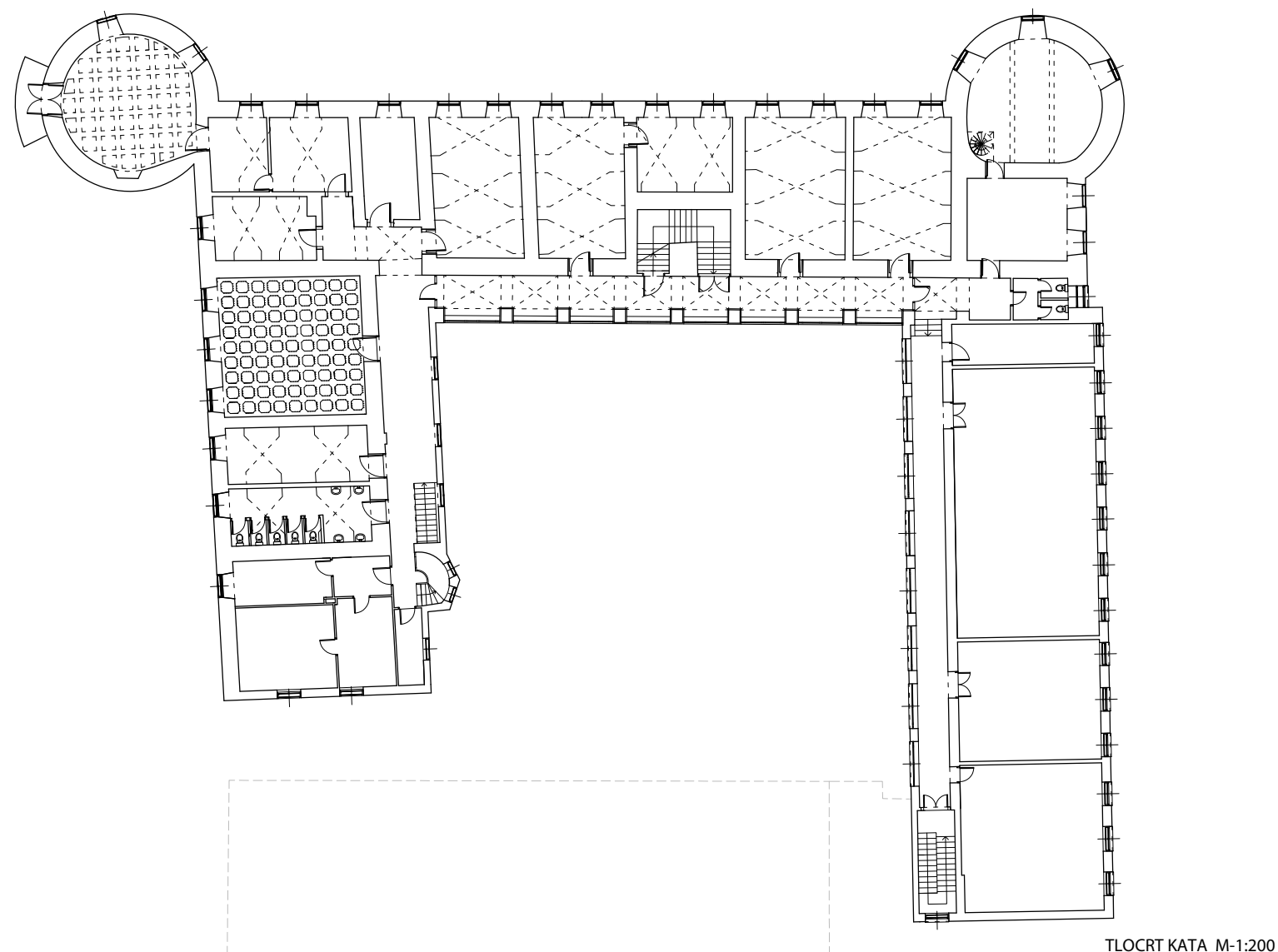

3. a - b Dvorac Kerestinec, tlocrt prizemlja i kata (izradila: T. Burić, 2011.) Kerestinec castle, layout of the ground and first floors (T. Burić, 2011) 


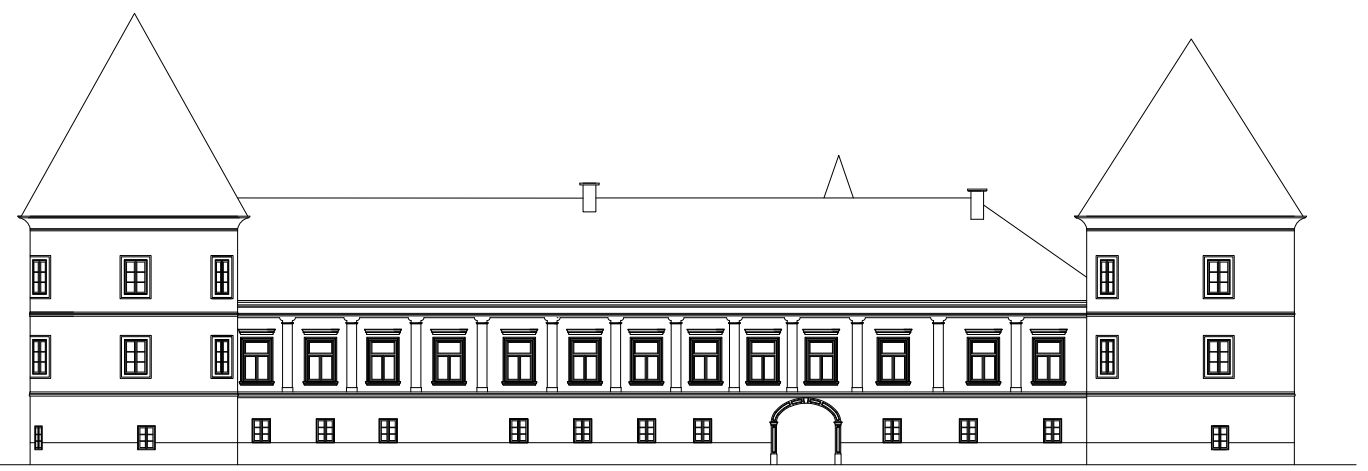

SJEVERNO PROČELJE

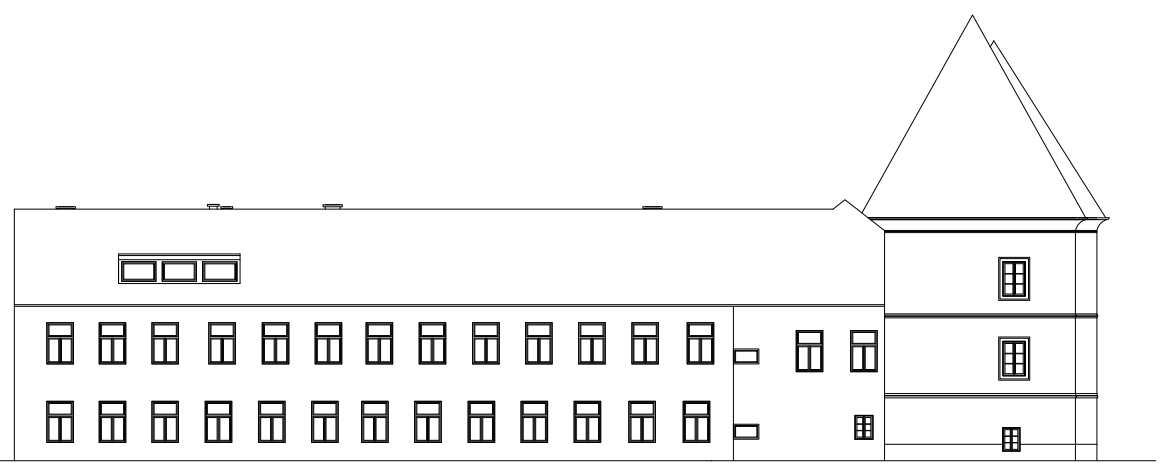

ISTOČNO PROČELJE

PROČELJA M-1:200

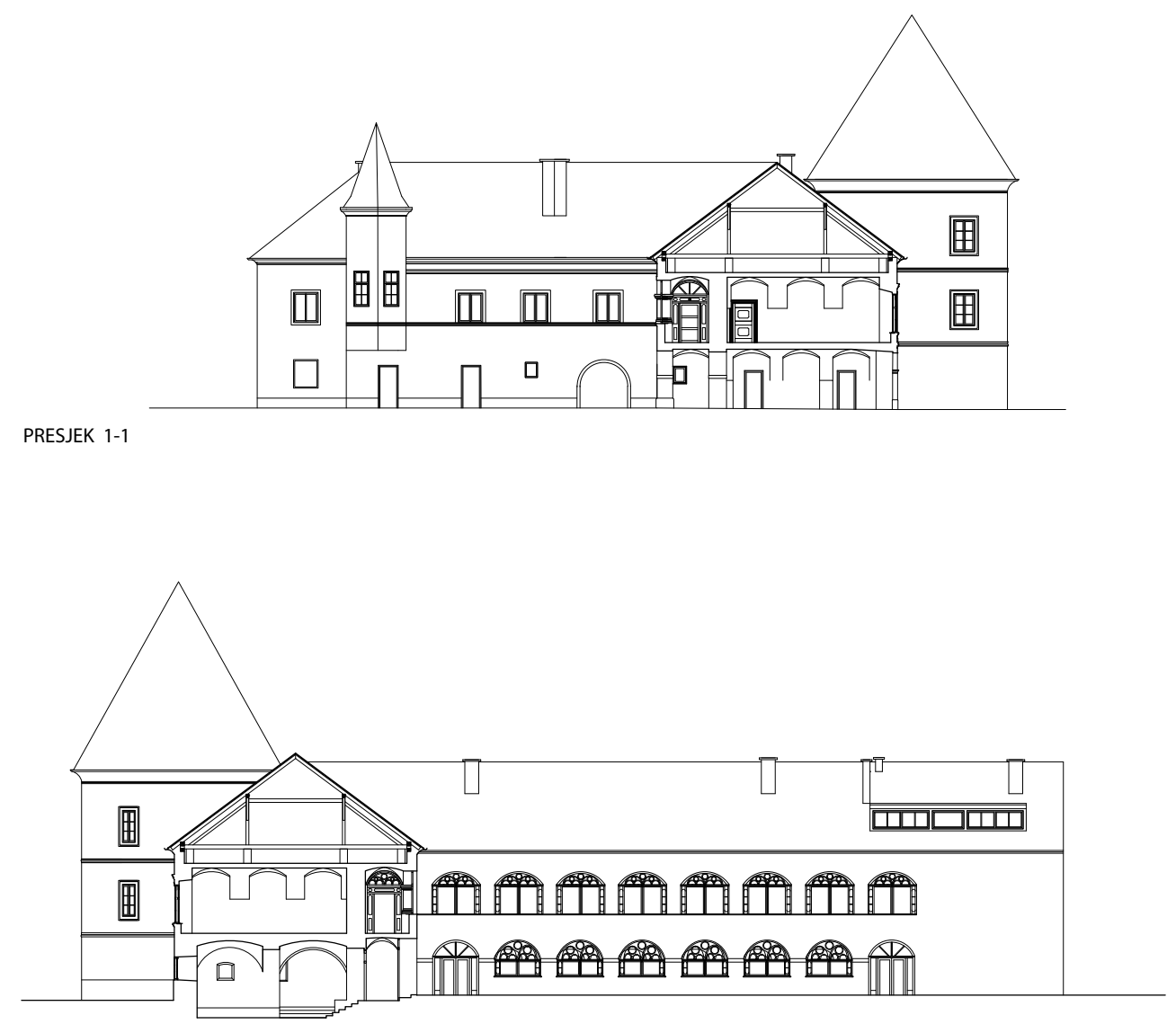

PRESJEK 2-2

PRESJECI M-1:200

4. a - b Dvorac Kerestinec, sjeverno i istočno pročelje, poprečni presjeci sjevernog krila s pogledom na dvorišno zapadno i dvorišno istočno pročelje (izradila: T. Burić, 2011.)

Kerestinec castle, north and east façade, cross-sections of the north wing and view of the west and east courtyard façades (T. Burić, 2011) 


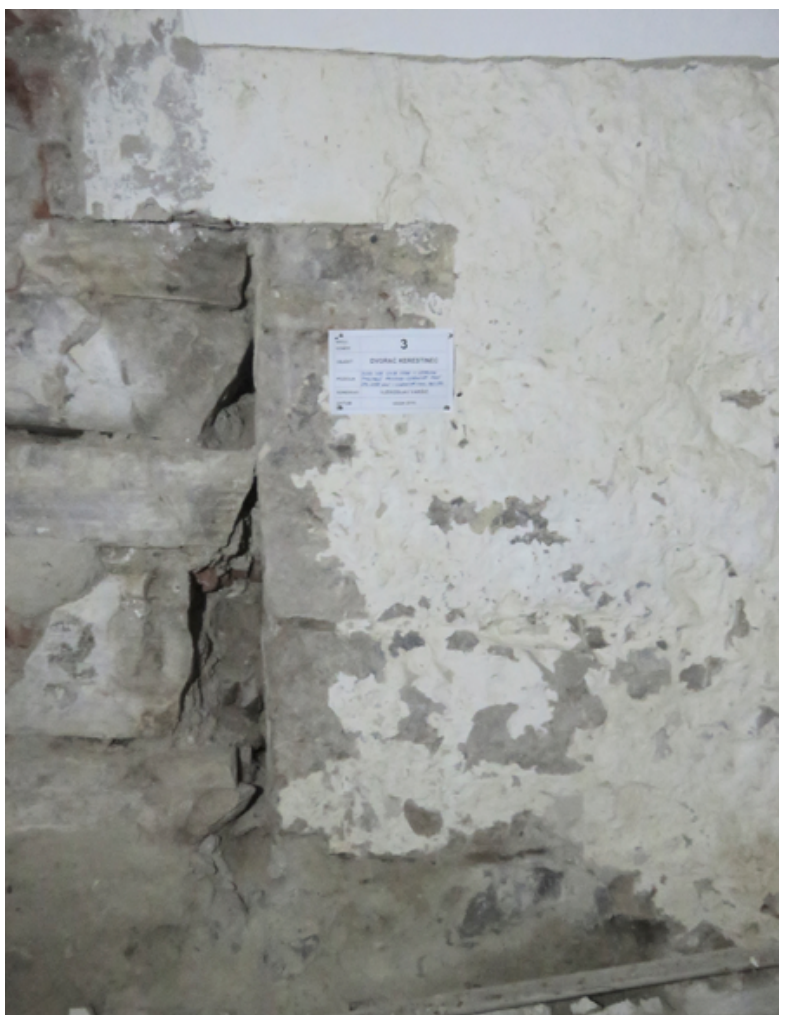

5. Dvorac Kerestinec, spoj najstarije zidane strukture s dograđenom sjeverozapadnom kulom (snimka: V. Jakaša Borić) Kerestinec castle, a combination of the oldest masonry structure with an extended northwest tower (V. Jakaša Borić)

interpretacije najranijih povijesnih slojeva ostaje na pretpostavkama. Prostorna su struktura i uređenje dvorca barokizacijskim zahvatima 18. stoljeća razjašnjeni temeljem detaljnog opisa dvorca iz inventara Kerestinca koji potječe iz 1847 . godine, ${ }^{8}$ vizitacijskih zapisa iz 1749. i 1852. godine, ${ }^{9}$ fotografija dvorišnih pročelja i vanjštine dvorca koje je svojom kamerom ovjekovječio zagrebački fotograf Ivan Standl ${ }^{10}$ neposredno nakon velikog potresa 1880. godine, te uz pomoć karte katastarske izmjere iz 1862. godine ${ }^{11}$ na kojoj je precizno prikazan tlocrtni obris tadašnjeg dvorca. Izmjene koje su nastupile krajem 19. i tijekom 20. stoljeća, rasvijetljene su analizom postojećeg stanja uz korištenje povijesne fotodokumentacije, podataka o izmjeni vlasnika i korisnika, kao i dostupnih informacija o određenim zahvatima (sl. 3 a i b, 4 a i b).

\section{Najstarija građevna struktura kurije, prva polovica 16. stoljeća (obitelj Herešinec)}

Najstariji građevni sloj dvorca Erdödy najvjerojatnije potječe iz razdoblja kada je kerestinečki posjed bio u vlasništvu obitelji Herešinec. ${ }^{12}$ Naime, J. Adamček spominje posjed kurije Kerestinec o kojem se 1560. godine brinu nećaci kanonika Jurja Heressynczyja, a prema E. Laszowskom, oko 1560. godine Petar II. Erdödy od Petra Herešinca, kupuje posjed u Kerestincu koji je bio pogodan za gospodarstvo. ${ }^{13}$

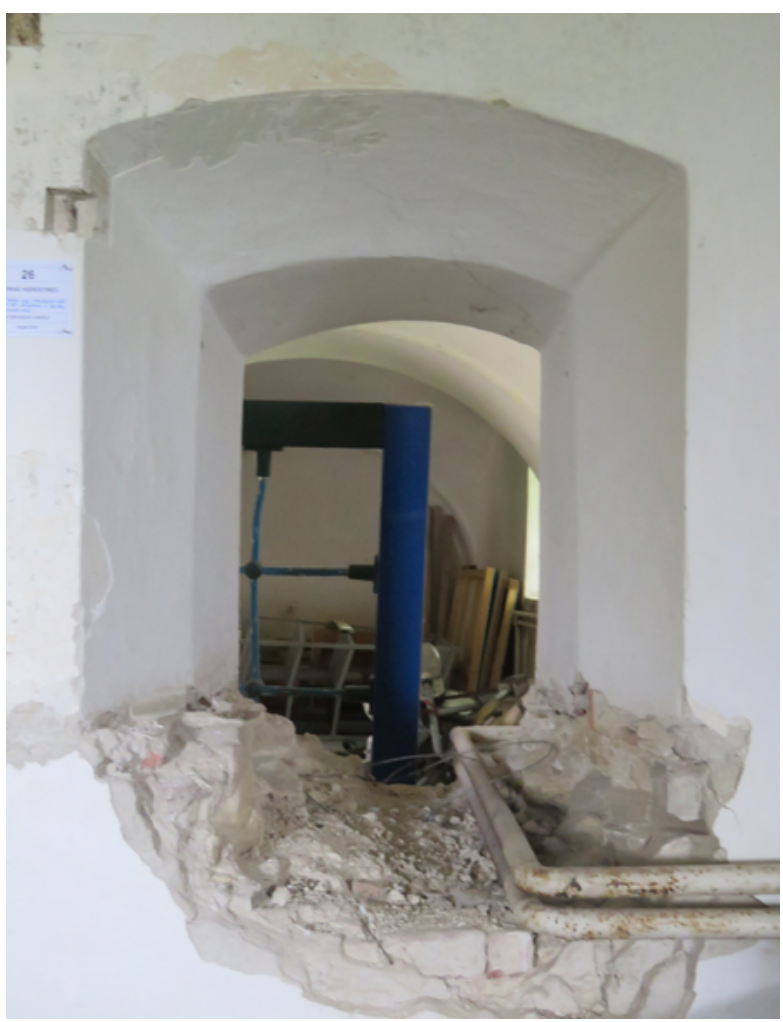

6. Dvorac Kerestinec, prozor koji pripada najstarijem građevnom sloju (snimka: V. Jakaša Borić, 2019.)

Kerestinec castle, a window from the oldest building phase (V. Jakaša Borić, 2019)

Na stariju zidanu strukturu, integriranu renesansnim kaštelom s obrambenim kulama koji je izgrađen tijekom posljednje trećine 16. stoljeća, ukazuju nalazi restauratorskih i građevinskih sondi. Volumen prvotne gradnje nije moguće u potpunosti definirati, međutim, na ključnim se mjestima dokazuje dogradnja dviju sjevernih kula starijem, tada već postojećem volumenu (ili volumenima), što otvara nove spoznaje i omogućava raslojavanje najstarijih građevnih struktura dvorca (sl. 5). ${ }^{14}$ Ovom sloju pripada i maleni prozor karakteristična oblikovanja na istočnom zidu prvotne kerestinečke gradnje, koji se dogradnjom sjeveroistočne kule i svođene prostorije s njezine južne strane, našao u zatvorenom prostoru i ostao tako bez funkcije (sl. 6). Srodni se nalazi, u vidu tankog sloja nepravilne vapnene žbuke sa slonokosno bijelim naličem, pojavljuju kod glavnog ulaza, na unutarnjoj strani sjevernog perimetralnog zida, gdje se kasnije dograđuje zid kojim se formira ulazna veža. ${ }^{15}$

Uzimajući u obzir nalaze konzervatorsko-restauratorskih istraživanja, a onda i moguće dispozicije volumena obzirom na postojeće debljine zidova i logiku prostora, može se svakako zaključiti da je prvotna gradnja vezana za perimetralne zidove sjevernog i zapadnog krila dvorca. Nije moguće sa sigurnošću tvrditi jesu li u pitanju bile dvije manje građevine - istočna, koja se pružala $u$ smjeru istok-zapad, i zapadna, koja se pružala u smjeru 


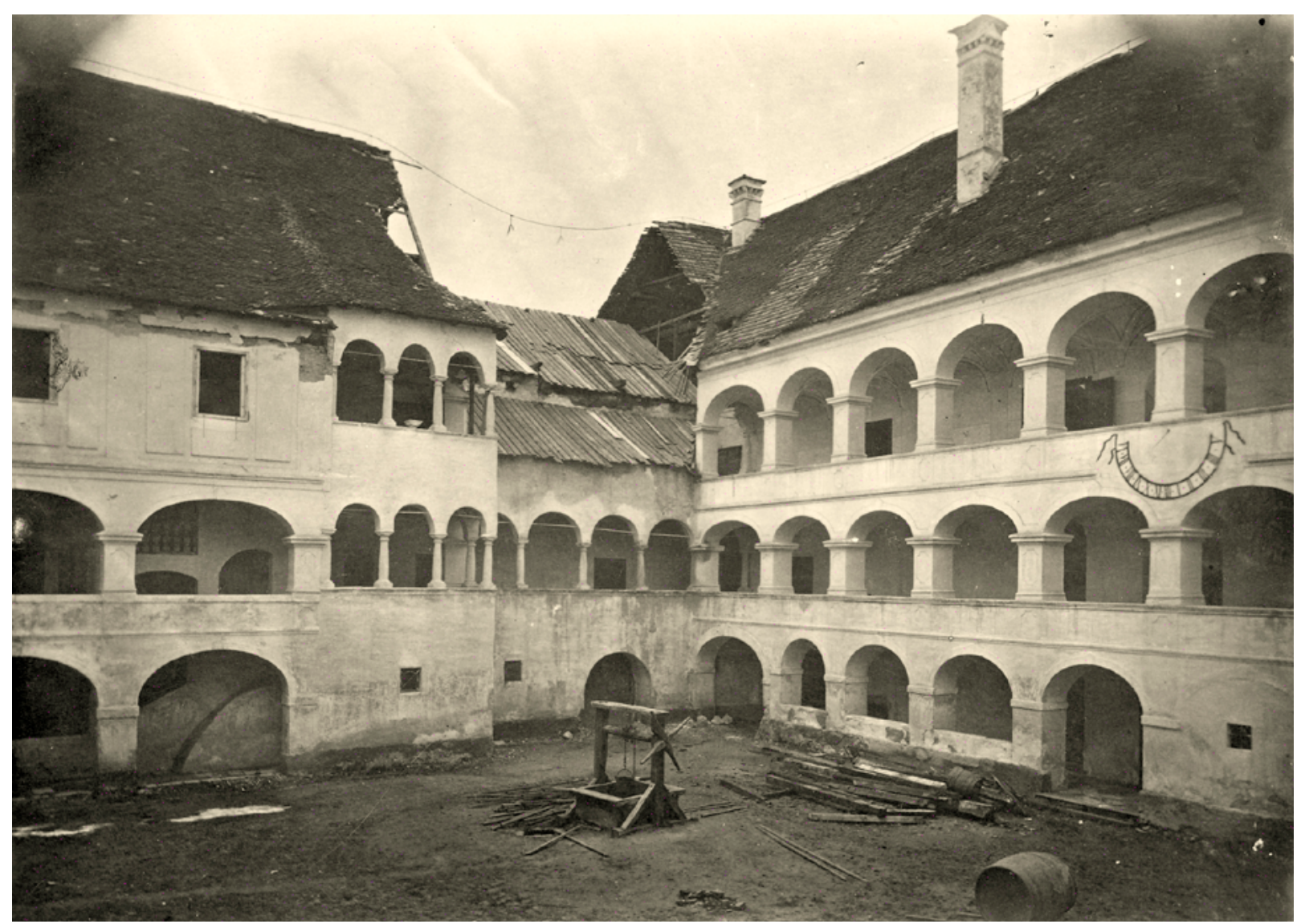

7. Dvorac Kerestinec, dvorišna pročelja zapadnog i sjevernog krila (MKM-FKB, snimka: I. Standl, 1880.) Kerestinec castle, courtyard façade of the west and north wings (MKM, FKB, I. Standl, 1880)

sjever-jug - ili je riječ je o povezanoj cjelini L tlocrtne forme. ${ }^{16}$ Zaključuje se da su dispozicija sjevernog i zapadnog krila renesansnog kaštela, kao i njihove osnovne dimenzije uvelike određene osnovnim gabaritima ranije postojeće gradnje.

\section{Formiranje kaštela s obrambenim kulama, druga polovica 16. stoljeća (Petar III Erdödy)}

Šesnaesto je stoljeće na ovim prostorima nemirno razdoblje obilježeno nezadovoljstvom i pobunama seljaka, koje završava 1573. godine Seljačkom bunom, kojom je zahvaćen i svetonedeljski kraj, osobito područje Kerestinca i Stupnika. Situaciju otežavaju stalni napadi turske vojske koji kulminiraju 1593., kada su poharane gospoštije Okić, Kerestinec, Jastrebarsko i Samobor. ${ }^{17}$ Upravno središte Okić $u$ to vrijeme prelazi u ruke nasljednika Tome Bakača (1442. - 1521.), nećaka Petra I. Erdödyja (1463. - 1547.) i njegova sina Petra II Erdödyja (1504. - 1567.), čija će djeca Petar III. Erdödy (1560. - 1613.) i Toma II. Erdödy (1558. - 1624.) zauvijek napustiti stari grad te se preseliti u novosagrađene nizinske kaštele u Kerestincu, Jastrebarskom i Novim Dvorima Klanječkim. ${ }^{18}$

Petar II. Erdödy kupuje posjed s kurijom u Kerestincu oko 1560. godine, u kojoj započinje graditi kaštel s obrambenim kulama koji će dovršiti njegov sin Petar III.
Erdödy, kapetan žumberački. Prema B. A. Krčeliću, kaštel je izgrađen oko 1575. godine, dok E. Laszowski navodi da se 1578. spominje "castellum Kerestinecz“, ${ }^{19}$ S obzirom na vrlo složenu i tešku situaciju, nastojeći što brže i ekonomičnije izgraditi kaštel, Petar Erdödy ne ruši, već integrira zatečenu građevinu u novu cjelinu dominantno obrambenog karaktera. ${ }^{20}$ Radovi na izgradnji kerestinečkog kaštela nisu izvedeni u dahu, štoviše, odvijali su se sukcesivno tijekom duljeg razdoblja, o čemu svjedoči zanimljiv podatak o tome da plemenita općina Cvetković u jednom dokumentu navodi da će Petru Erdödyju tijekom 1587. isporučiti 250 vozova kamena za gradnju i utvrđivanje Kerestinca. ${ }^{21}$ Dakle, izgradnja se kaštela $u$ nekoliko navrata intezivira, moguće i zbog oštećenja u Seljačkoj buni 1573. godine, a neupitno zbog kontinuiranih turskih napada, od kojih je najteži bio 1593. godine kada je Petar III. uspješno obranio svoj kaštel. Nakon uspostave Žitvanskog mira nastupa nešto mirnije razdoblje, stoga Petar III. nastavlja s uređenjem Kerestinca te ga prilagođava životu svoje obitelji. ${ }^{22} \mathrm{Uz}$ svetonedeljsku župnu crkvu Presvetog Trojstva, čiji je kolator, 1608. godine podiže kapelu sv. Petra, u kojoj će, zajedno sa svojom suprugom, biti sahranjen. ${ }^{23}$ Njegovi potomci predstavljaju hrvatsku granu obitelji koju čine njegovi sinovi Petar IV., Tomo III., Nikola II., Vuk I., Šimun, Valentin II. 


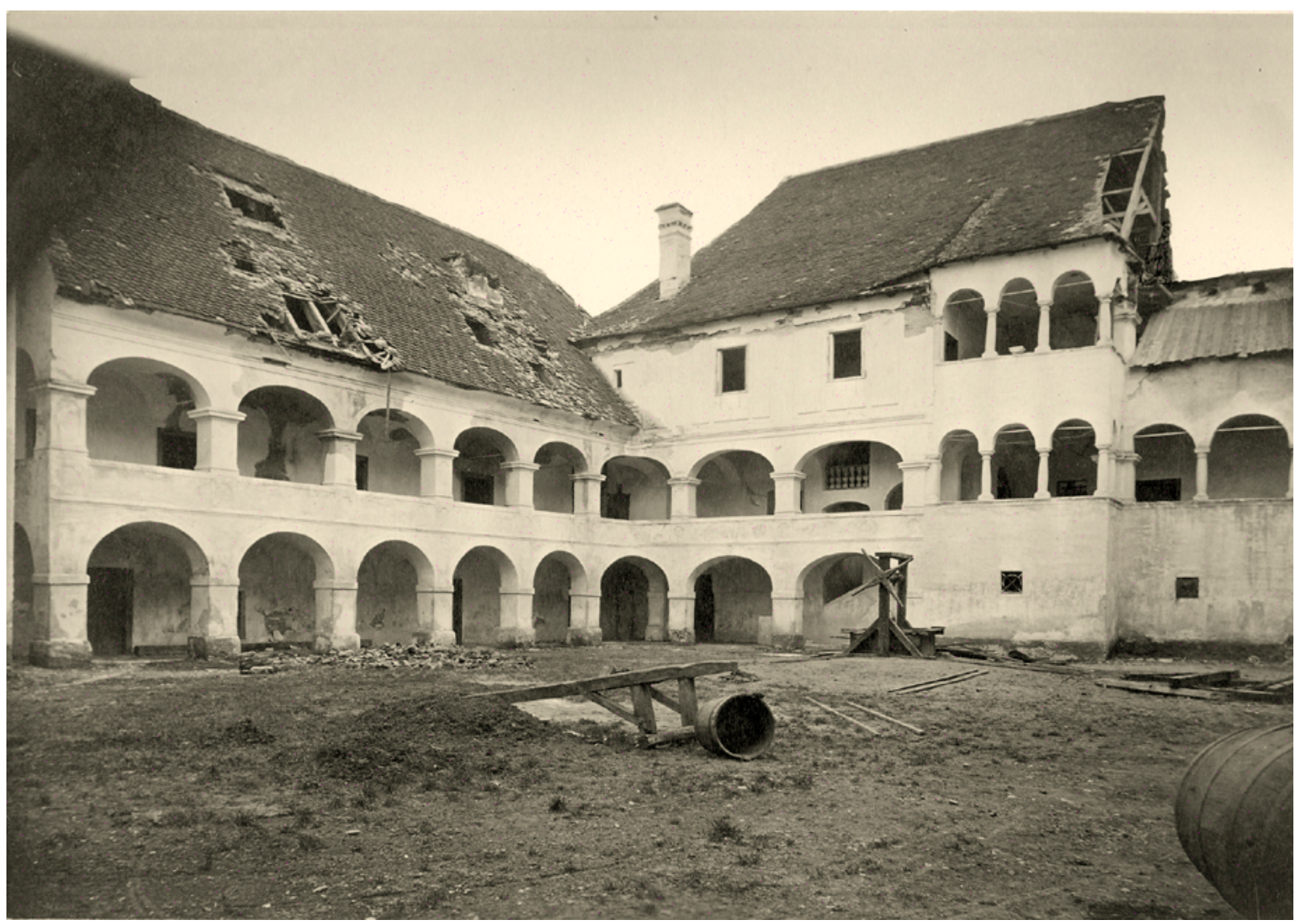

8. Dvorac Kerestinec, dvorišna pročelja južnog i zapadnog krila (MKM-FKB, snimka: I. Standl, 1880.)

Kerestinec castle, courtyard façade of the south and west wings (MKM, FKB, I. Standl, 1880)

i Franjo I., kćeri Barbara i Ana Marija te unuci Žigmund II., Nikola III., Juraj II., Vuk II. Sin Nikole III, Nikola IV. (1691. - 1706.) umire kao dijete za vrijeme školovanja u Grazu i s njim, 1706. godine, završava hrvatska grana obitelji Erdödy. ${ }^{24}$ Njezina će imanja već 1707 . godine, $u$ skladu s odlukom cara Josipa I., preuzeti ugarska grana Tome II., koja nastavlja obiteljsku lozu. ${ }^{25}$

Nizinski kaštel nastaje dogradnjom dviju sjevernih cilindričnih kula postojećim volumenima, koji postaju integralnim dijelom nove cjeline, pa njihovi vanjski zidovi preuzimaju ulogu perimetralnih zidova sjevernog $i$ zapadnog krila kaštela. Što se tiče južnog i istočnog dijela kaštela, moramo se zadržati na pretpostavkama s obzirom na to da je njihova kompletna građa, zbog štete nastale $\mathrm{u}$ velikom potresu 1880 . godine, uklonjena. ${ }^{26}$ Neupitno je, naime, postojanje dviju južnih kula, dok se na temelju katastarske karte iz 1862. godine, fotografija iz 1880. godine, a onda i komparativnih primjera nizinskih dvoraca iz istoga razdoblja, pretpostavlja da su južna i istočna strana kaštela bile zatvorene visokim zidovima. Ponekad, naime, zahtjevni četverokrilni planovi nisu mogli biti dovršeni, o čemu svjedoči i Ratkajev Mali Tabor, podignut na prijelazu 16. u 17. stoljeće, koji je uz četiri ugaone kule, imao samo dva krila, dok su ostale dvije strane dvorišta bile zatvorene zidom. ${ }^{27}$ Nekolicina dvoraca, poput Novih
Dvora Klanječkih iz 1603. godine ili dvorca Keglević u Pregradi s kraja 16. stoljeća, dokazuju da je jedna strana dvorišta često bila zatvorena samo zidom. ${ }^{28}$ Pretpostavku o dva zida kojima je dvorište kerestinečkog kaštela moglo biti zatvoreno podržava i činjenica da zapadno i sjeverno krilo imaju poluukopani podrum, dok južno i istočno krilo nije podrumljeno.

Zapadno je krilo zahvatima koje poduzima Petar III. Erdödy, izgrađeno kao dvokatno, što se zaključuje na temelju fotografija njegova dvorišnog pročelja, nastalih prije uklanjanja drugoga kata, dok pitanje postojanja drugoga kata sjevernog ulaznog krila u ovom razdoblju ostaje otvoreno. Dijelovi koji pripadaju ovom građevnom sloju razabiru se po obliku stupića prvoga i drugoga kata zapadnog krila, vezanih polukružnim lukovima kojima se uzdužni hodnici rastvaraju prema dvorištu (sl. 7 i 8). Stupići kružne osnove i blagog entazisa karakteristični su za kasnorenesansnu gradnju koja na ovim prostorima nastaje krajem 16. i početkom 17. stoljeća. Srodni oblici nalaze se u Novim Dvorima Klanječkim, koje podiže ista obitelj 1603. godine, kao i na dvorcu Ratkaj u Velikoj Horvatskoj iz 1611. godine. ${ }^{29}$

Prostorije unutar dvaju krila bile su organizirane $u$ jednostrukom nizu između dvorišnog i vanjskog obodnog zida. Poluukopanu podrumsku etažu zapadnog krila 


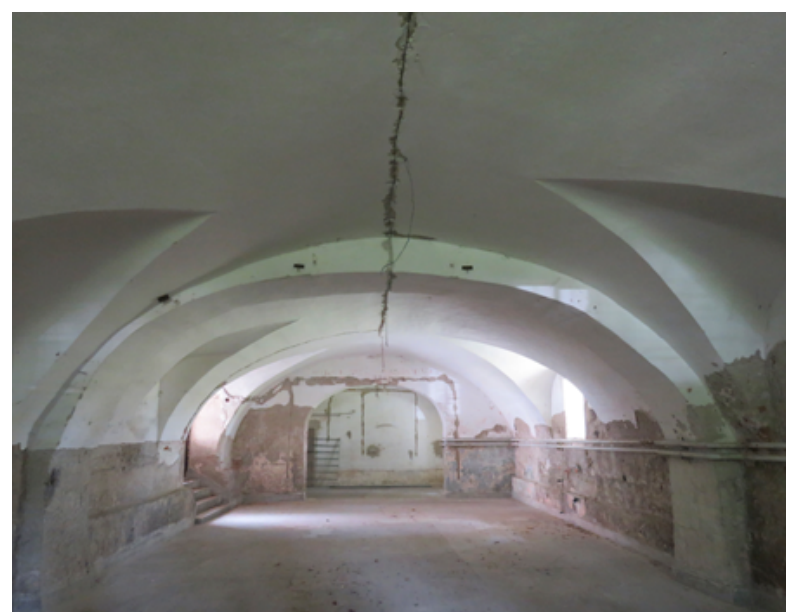

9. Dvorac Kerestinec, bačvasti svod poluukopane prostorije zapadnog krila (snimka: V. Jakaša Borić, 2019.)

Kerestinec castle, barrel vault of a half-buried room in the west wing (V. Jakaša Borić, 2019)

zauzimala je, i danas postojeća, izduljena, bačvasto svođena prostorija s duboko usječenim susvodnicama koja je vratnim otvorom bila spojena s prizemnom etažom sjeverozapadne kule (sl. 9). Duž dvorišnoga pročelja protezao se lučno rastvoreni trijem od tri travejna polja križnoga svoda, iz kojeg se spuštalo u podrumsku prostoriju. $\mathrm{Na}$ prvom su i drugom katu bili stambeni prostori, a horizontalnu su komunikaciju omogućavali hodnici, rastvoreni prema dvorištu ranije opisanim renesansnim arkadama. Iako nema materijalnih tragova stubišta, može se pretpotstaviti da je bilo smješteno u južnom dijelu krila. Već je tada ulaz u kaštel pozicioniran na današnjem mjestu, u zapadnom dijelu sjevernog krila, a veža je, prema nalazima sondi, u ovom razdoblju dobila svoju današnju tlocrtnu formu. ${ }^{30}$ Sjeverno je krilo u barokizaciji pregrađeno u svim etažama, stoga nije moguće govoriti o njegovoj prethodnoj prostornoj organizaciji, uključujući vertikalnu i horizontalnu komunikaciju.

Svaka od kula pokazuje određenu specifičnost. Naime, dvije se sjeverne kule, iako sličnih dimenzija (debljine zidova cca $130 \mathrm{~cm}$ ), na različit način vezuju za postojeću gradnju. Sjeveroistočna se kula dograđuje zajedno s jednoprostornim volumenom pravokutne osnove na koji se nadovezuje istočni perimetralni (obrambeni) zid kaštela, čime se formiralo dvorište, šire $u$ odnosu na opciju dogradnje same kule, kao što je to slučaj na zapadnoj strani, gdje se kula gradi u punoj kružnoj formi vezujući se za postojeću gradnju na samom uglu. ${ }^{31}$ Potonja je situacija najvjerojatnije proizašla iz tadašnjeg mogućeg stanja u kojem je zapadni perimetralni zid cijelom dužinom već postojao, zbog čega nije bilo mogućnosti širenja kao na istočnoj strani. Jugozapadna je kula poznata s fotografije zapadnog pročelja dvorca iz vremena nakon potresa 1880. godine (sl. 10). Već je na fotografiji očigledno da je većega promjera od sjeverozapadne kule, što potvrđuje katastarska izmjera iz 1862. godine, i što moguće ukazuje na drugačiji način korištenja ili različito vrijeme nastanka u odnosu na preostale tri kule, koje su ujednačenih dimenzija. ${ }^{32}$ Nije bila značajnije zahvaćena barokizacijom pa je u 19. stoljeću još imala puškarnice, a svojom jednostavnom vanjštinom daje naslutiti kako su izgledala pročelja renesansnog kaštela. Izgled jugoistočne kule nije poznat, samo katastarska izmjera iz 1862. svjedoči o njezinim tlocrtnim dimenzijama. Prema gore iznesenim pretpostavkama, kula je prvobitno bila vezana za južni i istočni obrambeni zid kaštela. Dvije su južne kule u prizemlju, prema opisu stanja iz 1847. godine, imale drvene grednike, vjerojatno još iz vremena njihove izgradnje. ${ }^{33}$ Bačvasti svod sa susvodnicama sjeveroistočne kule potječe iz vremena njezina nastanka, dok je svod sjeverozapadne kule vjerojatno nastao u barokizaciji, zamijenivši prvotni grednik.

Budući da je Kerestinec bio nizinski kaštel dominantno obrambenog karaktera, njegov je vanjski zidni plašt neupitno bio znatno manje rastvoren i skromnije dekoriran (ako je dekoracija uopće i postojala) u odnosu na nadolazeće razdoblje barokizacije. Glavni je ulaz bio na današnjem mjestu, međutim, temeljem brojnih komparativnih primjera, pretpostavlja se da je tadašnji portal imao polukružni zaključak. ${ }^{34}$ Pročeljne su plohe bile zaglađene vapnenom žbukom i bojane slonokosno bijelim vapnenim naličem.

\section{Barokizacija renesansnog kaštela, 18. stoljeće (obitelj Erdödy)}

Društveno-politička situacija postupno se mijenjala, što je bilo usko vezano uz povlačenja turske vojske s ovih prostora nakon potpisivanja Žitvanskog mira 1606. godine, kojim se uspostavlja čvršći vojni pojas pa život u njegovom zaleđu postaje nešto sigurniji. Ipak, turska je opasnost $u$ potpunosti nestala tek nakon potpisivanja mira u Sremskim Karlovcima 1699., nakon velike pobjede Eugena Savojskog. ${ }^{35}$ Ove su okolnosti uvelike utjecale na način života u cijeloj kontinentalnoj Hrvatskoj, pa tako i na područje Okićke gospoštije, odnosno svetonedeljski kraj, u kojem se tijekom 18. stoljeća uspostavljaju prometne veze, oživljavaju trgovina i poljoprivreda, a obnavlja se i duhovni život o čemu svjedoči dogradnja i uređenje župne crkve Presvetog Trojstva te dviju kapela (Sv. Rok u Svetoj Nedelji i Sv. Marija Magdalena u Maloj Gorici). ${ }^{36}$ Mir i sigurnost odražavaju se i na arhitektonskom oblikovanju rezidencijalne izgradnje. Nekadašnje je kaštele trebalo prilagoditi drugačijim potrebama, stoga ranije dominantni obrambeni elementi ove izgradnje iščezavaju ili se koriste na nov način, s naglaskom na udobnosti i reprezentativnosti. Kako se vrijeme navedenih promjena podudara $\mathrm{s}$ razdobljem $\mathrm{u}$ kojem se na ovim prostorima afirmira barok, barokizacijama postojećih građevina mijenja se njihov karakter te se zadovoljavaju potrebe novog načina 


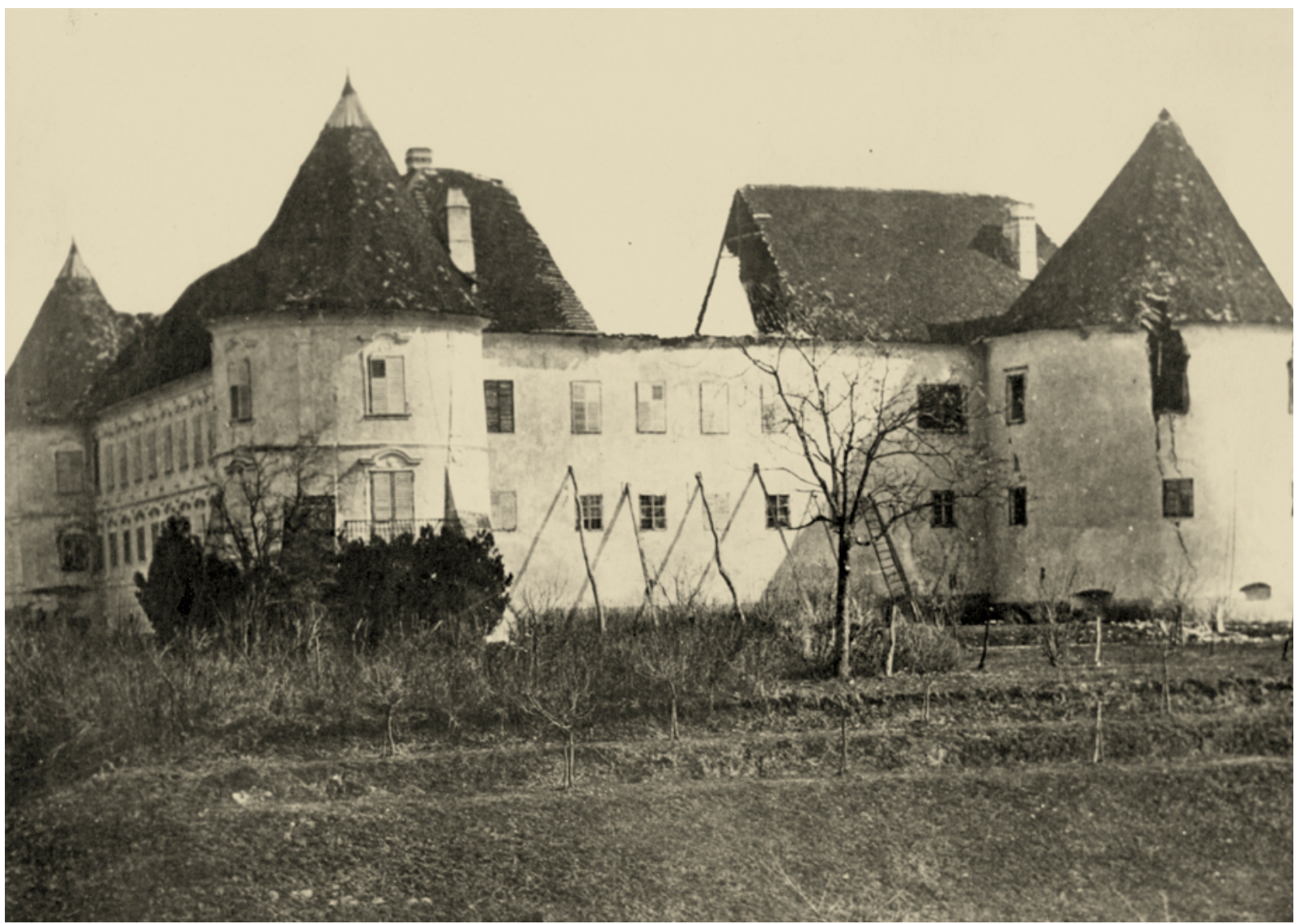

10. Dvorac Kerestinec, pogled na dvorac sa zapada (MKM-FKB, snimka: I. Standl, 1880.)

Kerestinec castle, view of the castle from the west (MKM-FKB, I. Standl, 1880)
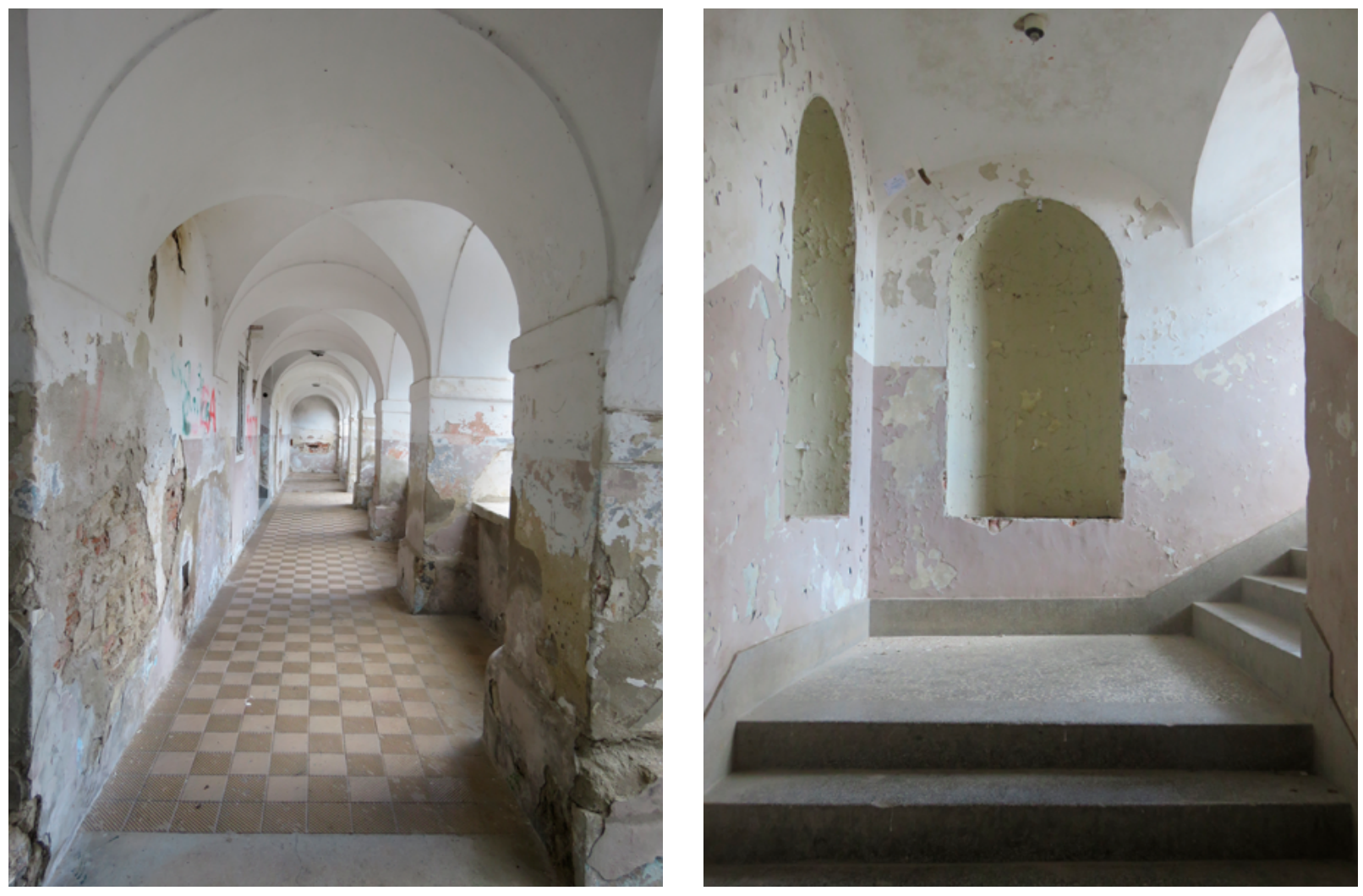

11. a - b Arkadni trijem u prizemlju sjevernoga krila dvorca Kerestinec, barokno stubište s nišama (snimka: V. Jakaša Borić, 2019.) Kerestinec castle, arcade porch on the ground floor of the north wing, Baroque staircase with niches (V. Jakaša Borić, 2019) 


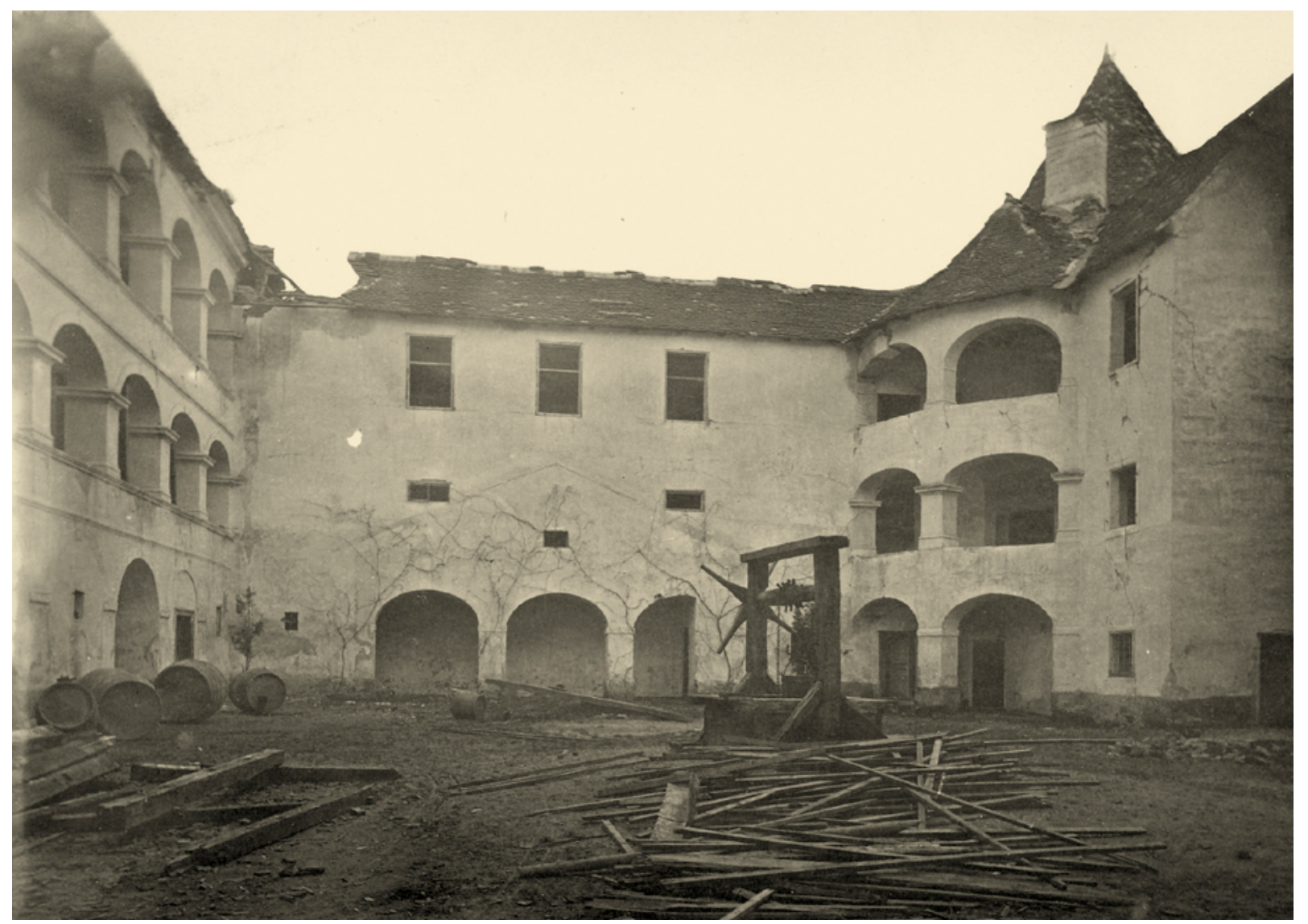

12. Dvorac Kerestinec, dvorišno pročelje istočnog krila (MKM-FKB, snimka: I. Standl, 1880.) Kerestinec castle, courtyard façade of the east wing (MKM-FKB, I. Standl, 1880)

života. Barokizacijske zahvate osuvremenjivanja dvorca u Kerestincu poduzimaju pripadnici ugarske grane obitelj Erdödy, u čijem vlasništvu dvorac ostaje do 1852. godine, kada se imanje, nakon što je bilo zahvaćeno sekvestrom, prodaje sudskim putem. $^{37}$

Sjeverno je krilo u ovom razdoblju velikim građevinskim zahvatima značajno izmijenjeno bez obzira na to je li drugi kat $u$ potpunosti nadograđen ili je obnavljan s ciljem uređenja reprezentativnih stambenih prostorija. Ovu tvrdnju potkrjepljuje i gradnja trokrakog kamenog stubišta ${ }^{38}$ s nišama, a dodavanje arkadno rastvorenih hodnika te nužno izvođenje novoga krovišta, dokazuju da su intervencije bile doista obimne (sl. 11 a i b). Nadalje, ugradnjom stubišta mijenja se raspored prostorija prizemlja i kata, a istovremeno se izvode i nove svodne konstrukcije $u$ vidu bačvastih svodova zasječenih susvodnicama prelomljenih bridova koji zamjenjuju starije drvene stropove. ${ }^{39} \mathrm{U}$ ovom razdoblju i ulazna veža, premda tlocrtno već ranije formirana, dobiva bačvasti svod s istim tipom susvodnica. ${ }^{40} \mathrm{U}$ poluukopanoj podrumskoj etaži na istočnom rubu prema kuli formira se veća prostorija od četiri travejna polja čeških kapa, čije pojasnice podržava masivni četvrtasti stup u središtu. U skladu s tendencijama vremena i novim okolnostima, sjeverne kule preuzimaju stambenu funkciju, zbog čega se rastvaraju prozorima, a uvođenjem barokne arhitektonske plastike cijeli sjeverni dio dvorca, s orijentacijom na perivoj, postaje reprezentativna dominanta cjeline. ${ }^{41}$ Među značajne promjene ovoga razdoblja ubraja se i formiranje jednokatnog južnog krila s dvorskom kapelom i arkadno rastvorenim hodnicima, kao i uspostava sasvim uskog dvokatnog istočnog krila s funkcijom komunikacije ili hodnika koji omogućava ophod dvorca (sl. 12). ${ }^{42}$ Nakon barokizacije, kojom se realizira četverokrilni koncept, dvorac ostaje zatvoreni četverokut s ugaonim kulama i glavnim ulazom na ranijoj poziciji izvan centralne osi, bez naznaka arhitektonske sistematizacije koja bi se očitovala $u$ aksijalnom komponiranju prostora i volumena, kao i rastvaranju, odnosno povezivanju s vanjskim prostorom. Osnovna horizontalna komunikacija svih etaža odvijala se lučno rastvorenim hodnicima s orijentacijom na dvorište. Na Standlovim fotografijama barokne polueliptične forme lukova otkrivaju dijelove dograđene u okviru barokizacije. Ovi su hodnici bili svođeni križnim svodovima, o čemu svjedoče dijelovi, očuvani do danas, unutar sjevernoga krila, kao i jedna od spomenutih fotografija iz 1880. godine. ${ }^{43}$

Iz opisa dvorca iz 1847. godine mnogo se saznaje o prostornoj organizaciji i interijeru koji je tada već dosta zapušten i u lošem stanju, što nam govori da je dosta vremena prošlo od njegova posljednjeg uređenja te navodi na 
zaključak da opisana situacija potječe iz vremena barokizacije. $^{44} \mathrm{U}$ tekstu se, osim opisa opreme svake prostorije (podovi, svodovi i stropovi, stolarija, dekorativni elementi), navodi i njihova namjena, što ocrtava karakter i način korištenja svake etaže. Prizemlje je imalo gospodarsku i utilitarnu funkciju, o čemu svjedoče sobe za pohranu raznih namirnica, kuhinja, ljevaonica (ustrina), manja soba za pepeo (camerula pro cineribus), soba pekača kruha (camera panis pistorea), soba za potkove (camera pro ferro), tamnica (carcer), sobe za sluge, soba stražara (cubile vigilum), dok je prvi kat, s nekoliko gospodarskih prostorija, imao primarno poslovnu namjenu. Tu se navodi blagajnička soba (camera cassae), prostorija arhiva, prostorije za smještaj službenika, sobica za čuvanje jabuka i krušaka, mala kuhinja, ostava. Prostorije su prvoga kata, očito namijenjene službenicima koji su vodili i brinuli se o vlastelinstvu, bile vrlo jednostavno i funkcionalno opremljene. Gotovo sve su imale pod od dasaka, željezne peći te su bile svođene. U opisu prvoga kata južnoga krila navodi se kapela i još četiri manje sobe, od kojih je jedna bila namijenjena kapucinu.

Posebno je zanimljiv opis prostorija drugoga kata koji otkriva neočekivanu reprezentativnost i raskoš uređenja ovih interijera. Prostorije sjevernog i zapadnog krila, kao i kružne sobe triju kula (osim jugoistočne), imaju drvene podove i tabulatne stropove. Međusobno su uglavnom povezane dvostrukim hrastovim vratima formirajući enfilade. Neke se ističu opremom i veličinom, poput blagovaone (Tafelzimmer), prostorije unutar sjevernog krila $\mathrm{s}$ čak pet prozora i drvenim stropom od četvrtasth ploča koje se isprepliću s križnim formama (moguće kasetirani stropa), a koji podržavaju četiri marmorizirana stupa, dok je dvostrukim pozlaćenim vratima umjetničke izrade povezana s prostorijom dnevnog boravka (Sitzimmer). ${ }^{45}$ Ova prostorija, sa samo dva prozora, ima strop od crnobijelih četvrtastih ploča, zidovi su prekriveni pohabanim tapetama od papira, peć je umjetnički izrađena s kipom na vrhu, a ima i uzidano ogledalo. ${ }^{46}$ Lučnim je otvorom vezana za prostoriju unutar kule (sjeverozapadne), koja ima kamin s kipom Cerere, strop od četvrtastih crno-bijelih ploča, marmorizirane zidove i tri prozora, a dvostrukim pozlaćenim vratima za prostoriju zapadnog krila s dva uzidana ogledala, drvenim stropom i bijelom peći. ${ }^{47}$ Unutar zapadnog krila nižu se manje prostorije, garderoba i kabinet, također s drvenim stropovima i zidovima prekrivenim tapetama, te zahodi, prostorija sobarice i napokon garderobe (Garderobzimmer) u jugoistočnoj kuli. Unutar jednokatnog južnog krila, osim kapele koja zaprema visinu dviju etaža, na prvom se katu nalazi nekoliko manjih soba stropnog zaključka od kojih je jedna bila namijenjena kapucinu.

Na Szemanovoj je karti iz 1822. godine Kerestinec naznačen simbolom koji podrazumijeva dvorac s kapelom - Castellum Familiae cum Sacello. ${ }^{48}$ Isčitavanjem

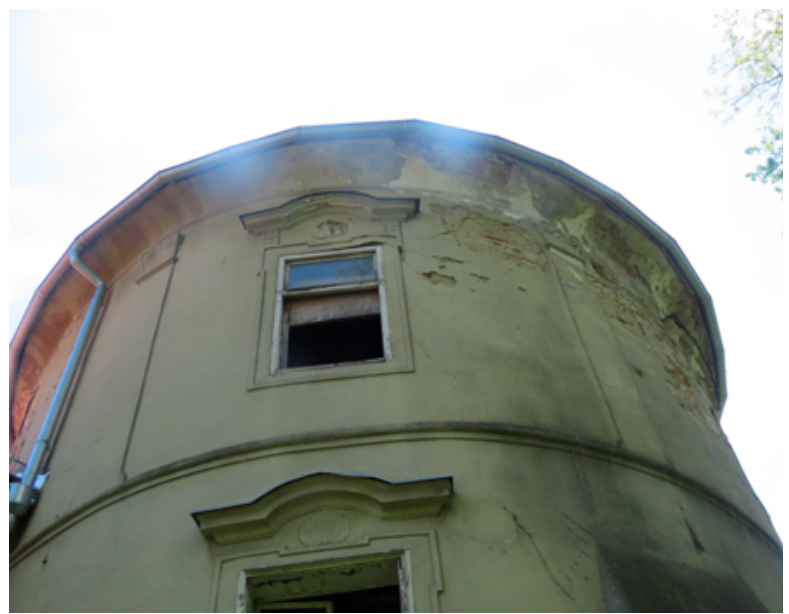

13. Barokna arhitektonska plastika na pročelju sjeverozapadne kule dvorca (snimka: V. Jakaša Borić, 2019.)

Baroque architectural sculptures on the façade of the northwest tower (V. Jakaša Borić, 2019)

vizitacijskih tekstova utvrđeno je da je dvorska kapela bila posvećena Blaženoj Djevici Mariji od Navještenja, da ju je blagoslovio biskup Branjug 1735. godine, a da je naručitelj bio grof Ladislav Erdödy od Monyorókeréka. ${ }^{49}$ Smještena unutar južnoga krila dvorca, u osi ulazne veže, orijentacije sjever-jug, svojim je polukružnim svetištem izlazila iz ravnine njegova perimetralnog zida, što je jasno prikazano katastarskom izmjerom dvorca iz 1862. godine. Prema opisu iz 1847. godine, bila je svođena, imala je pod od dasaka, tri prozora i zvonik s jednim zvonom, a od opreme oltar s posvećenim kamenom, dvije klupe te potrebno misno posuđe i ruho. ${ }^{50}$

Barokizacija donosi i obnovu pročelja dvorca, pri čemu se uvođenjem bogatije arhitektonske plastike, naglašava i objedinjuje pročeljni plašt sjevernog krila i prenamijenjenih sjevernih kula. Što se prozorskih otvora tiče, blago nepravilni ritam, koji se i danas razabire na ovom pročelju, govori da su neki od prozora ranije postojali, odnosno da su barokni prozori bili prilagođeni zatečenoj situaciji. S obzirom na to da žbukani sloj iz ovoga razdoblja na sjevernom pročelju nije očuvan, Standlova je fotografija vanjštine dvorca iz 1880. godine ključna i donosi niz podataka o njegovu oblikovanju. Riječ je o karakterističnom konceptu koji se javlja na ovim prostorima od četrdesetih godina 18 . stoljeća, a temelji se na horizontalnoj podjeli provedenoj razdjelnim vijencima kao i obradi prizemne zone rustikom u žbuci, dok su katne etaže bile artikulirane gustim ritmom pilastara kojima su formirana prozorska polja. ${ }^{51}$ Plastični su naglasak predstavljale razgibane prozorske nadstrešnice prozora prvoga i drugoga kata. Kako je drugi kat bio namijenjen životu plemstva, njegov reprezentativni karakter istaknut je naglašenijom vertikalnom mjerom, odnosno većim prozorima $u$ odnosu na prvi kat na kojem su bile smještene poslovne prostorije. Razlikovanju doprinosi i 


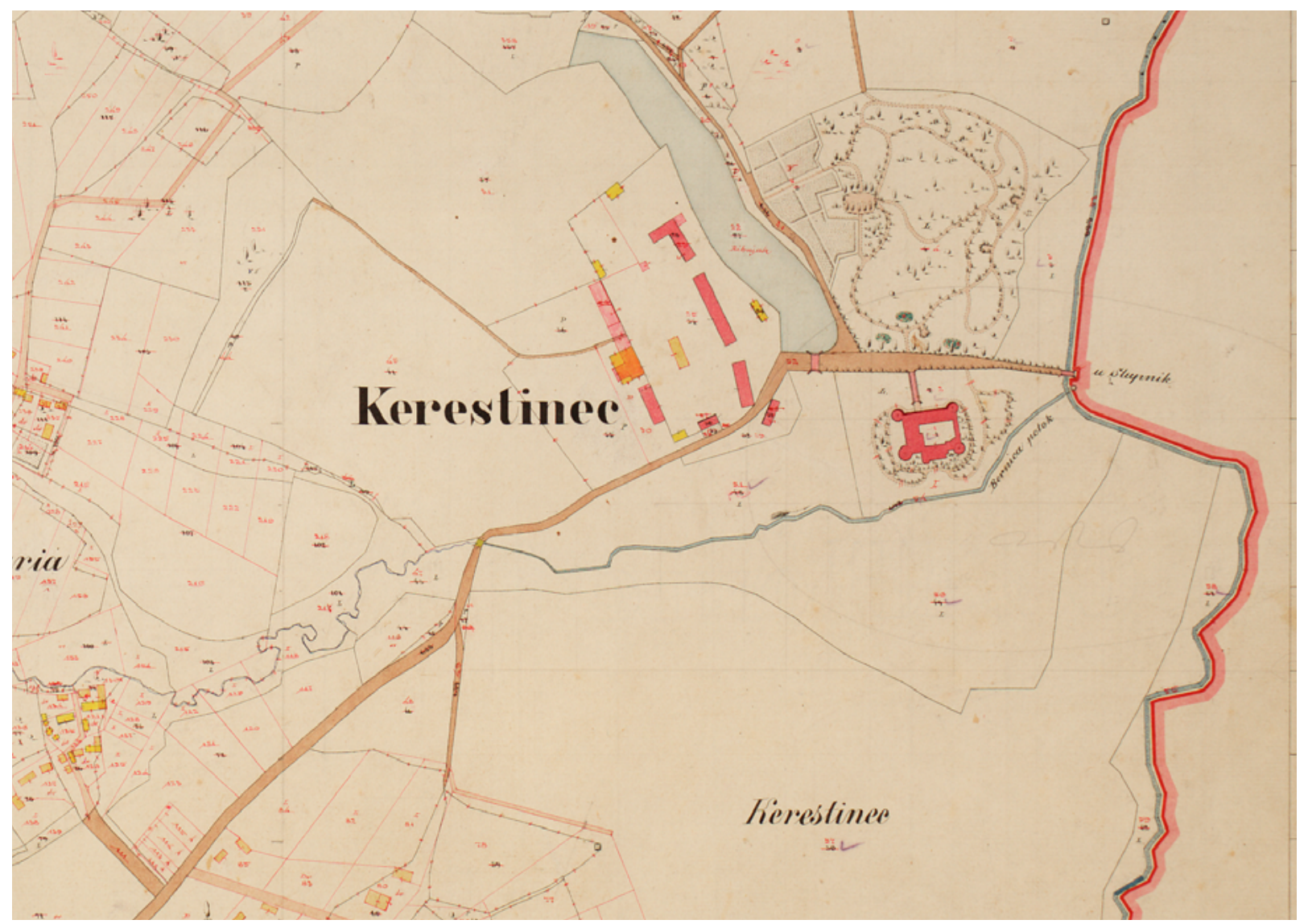

14. Karta katastarske izmjere (HDA-DGU, 1862.)

Map of cadastral survey (HDA-DGU, 1862)

arhitektonska plastika parapetnih zona prozora drugoga kata, koja u zoni prvoga kata izostaje. Do danas je jedini sačuvani element sjevernog pročelja iz vremena barokizacije portal polueliptoidnog zaključka i naglašene kapitelne profilacije, dekoriran pločastim izduljenim formama odrezanih uglova, utisnutima $u$ upuštena polja dovratnika i lučnog nadvoja. Za razliku od sjevernog pročelja, s kojega je barokna žbuka u kasnijoj obnovi uklonjena, na kulama je ovaj sloj očuvan, stoga barokna arhitektonska plastika, kao vrijedno svjedočanstvo obnove pročelja koja se odvijala moguće oko sredine 18. stoljeća, postoji i danas (sl. 13). Po tri prozora u svakoj etaži imaju barokne okvire s pravokutnim istacima („uškama“) i razgibane profilirane nadstrešnice s motivom rastvorene školjke, dok su plohe katnih etaža raščlanjene glatkim pilastrima jednostavne kapitelne dekoracije $u$ formi plitkih voluta. Prozori drugoga kata i ovdje imaju dekorativni dodatak između prozorskog okvira i nadstrešnice $u$ vidu plitke konzole s motivom diskova.

Dvorišna su pročelja dograđenih, lučno rastvorenih hodnika barokizacijom dobila jednostavniju arhitektonsku plastiku koja na plohama sjevernog krila postoji i danas. ${ }^{52}$ Osim kapitelnih istaka $u$ vidu glatkih traka na zidanim stupovima prizemlja i kapitelne profilacije stupova prvoga kata, kao plastična raščlamba i dekoracija vanjskih ploha stupova prvoga kata i njihovih parapeta koriste se upuštene forme kvadriloba - pravokutnika i kvadrata, odsječenih, konkavno zaobljenih stranica. Riječ je varijaciji medaljonske raščlambe, što je posljednjih desetljeća 17. stoljeća u Grazu bio arhitektonski trend koji će imati značajnog odjeka u sjeverozapadnoj Hrvatskoj već potkraj stoljeća. ${ }^{53}$ Pitanje vremena izgradnje arkadnih hodnika vezuje se uz korištenje tradicionalne forme križnih svodova, koja je na ovim prostorima karakteristična za cijelo 17. i početak 18. stoljeće, kao i uz dekoraciju kvadrilobima (medaljonima) u žbuci, koja se počinje koristiti potkraj 17. stoljeća, ali i uz činjenicu da je dvorska kapela izgrađena 1735. godine u okviru južnoga krila koje se formira barokizacijom. Uzimajući u obzir sve navedeno, može se pretpostaviti da su arkadni hodnici izvedeni na prijelazu 17. u 18. stoljeće ili tijekom prve trećine 18. stoljeća.

\section{Dvorac i imanje sredinom 19. stoljeća (obitelj Pallavicini)}

Dvorac je u vlasništvu obitelji Erdödy do 1852. godine, kada su ga bili prisiljeni prodati zbog financijskih problema. ${ }^{54}$ Kupuje ga obitelj talijanskog porijekla Pallavicini, a prvo je svjedočanstvo o prisutnosti novih vlasnika na kerestinečkom imanju popis čestica s imenima vlasnika iz 1862. godine, u kojem se navodi Hipolit Pallavicini. ${ }^{55}$ Ova obitelj 
vjerojatno obnavlja dvorac, o čijem je lošem i zapuštenom stanju svjedočio opis iz 1847. godine, međutim, čini se da ne poduzima značajnije građevinske zahvate koji bi imali utjecaja na njegov prostorni koncept, volumen ili pročeljnu artikulaciju. Aktivno nastavlja s uređenjem i širenjem engleskog perivoja, uređuje veliki ribnjak $u$ sjeverozapadnom dijelu imanja, kao i šetnicu uz njegovu istočnu obalu (sl. 14). ${ }^{56}$ Karta katastarske izmjere iz 1862., osim relativno preciznog tlocrta četverokrilnog dvorca sa četiri kule, donosi i detaljan prikaz imanja koje svojom koncepcijom predstavlja tipično vlastelinstvo toga vremena. U sjevernom dijelu, nasuprot dvorcu nalazi se relativno veliki perivoj engleskog tipa s vijugavim stazama i geometrijski organiziranim povrtnjakom u rubnom dijelu prema ribnjaku. Izduljeni ribnjak sa šetnicom duž istočne obale dijeli ovo područje od gospodarske zone, formirane prema zapadu, s većim brojem gospodarskih zgrada.

\section{Obnova dvorca nakon oštećenja nastalih u potresu 1880. godine (obitelj Türk) i ostali zahvati 20. stoljeća}

Potres je 1880. godine ozbiljno oštetio dvorac, koji je tada još uvijek bio u vlasništvu obitelji Pallavicini, a ranije spominjane fotografije Ivana Standla svjedočanstvo su njegova izgleda iz toga vremena kao i velike štete koje mu je potres nanio. Pallavicini, međutim, nisu uspjeli dovršiti obnovu dvorca, već ga potkraj stoljeća prodaju karlovačkoj obitelji Türk. Njihovu prisutnost u dvorcu, koja je zabilježena 1897. godine ${ }^{57}$, dokazuje i raskošan obiteljski grb izrađen u pečenoj glini (sl. 15). Sa svoje prvotne pozicije na pročelju, prebačen je $u$ jednu od prostorija prizemlja sjevernog krila dvorca, gdje se nalazi danas. Velike zahvate obnove ozbiljno ugroženog dvorca poduzima Franjo Aurel Türk (1867. - 1920.), ugledni građanin Karlovca, trgovac koji je posjedovao brojna imanja. ${ }^{58}$

Značajne se promjene događaju uklanjanjem dviju južnih kula te dokidanjem drugoga kata sjevernog i zapadnog krila dvorca, o čemu svjedoče fotografije s početka i prve polovice 20. stoljeća (sl. 16). ${ }^{59}$ Istovremeno se obnavlja glavno sjeverno pročelje, ponavljanjem baroknog koncepta ritmiziranjem pročeljnog platna katne etaže gustim nizom pilastara. ${ }^{60}$ Unutar polja formiranih pilastrima su prozori, povećani u odnosu na prethodne, s ravnim profiliranim nadstrešnicama umjesto razgibanih baroknih koje se razabiru na fotografiji Ivana Standla. Na pročeljima kula zadržava se barokna artikulacija i arhitektonska plastika. ${ }^{61}$ Interijer se još jednom, u duhu vremena obnavlja pa se unutar zapadnog krila uređuje svečana dvorana, pri čemu se barokne svodne konstrukcije mijenjaju kasetiranim drvenim stropom (sl. 17), jednako kao i u katnoj prostoriji sjeverozapadne kule. ${ }^{62} \mathrm{O}$ uređenju dvorca iz ovoga razdoblja svjedoči i kružna prostorija drugoga kata sjeverozapadne kule $u$ kojoj su očuvane zidne štukature $u$ formi visećih isprepletenih šiljatih lukova. Dvorišno pročelje zapadnog krila s erkerom kojim dominira šiljata

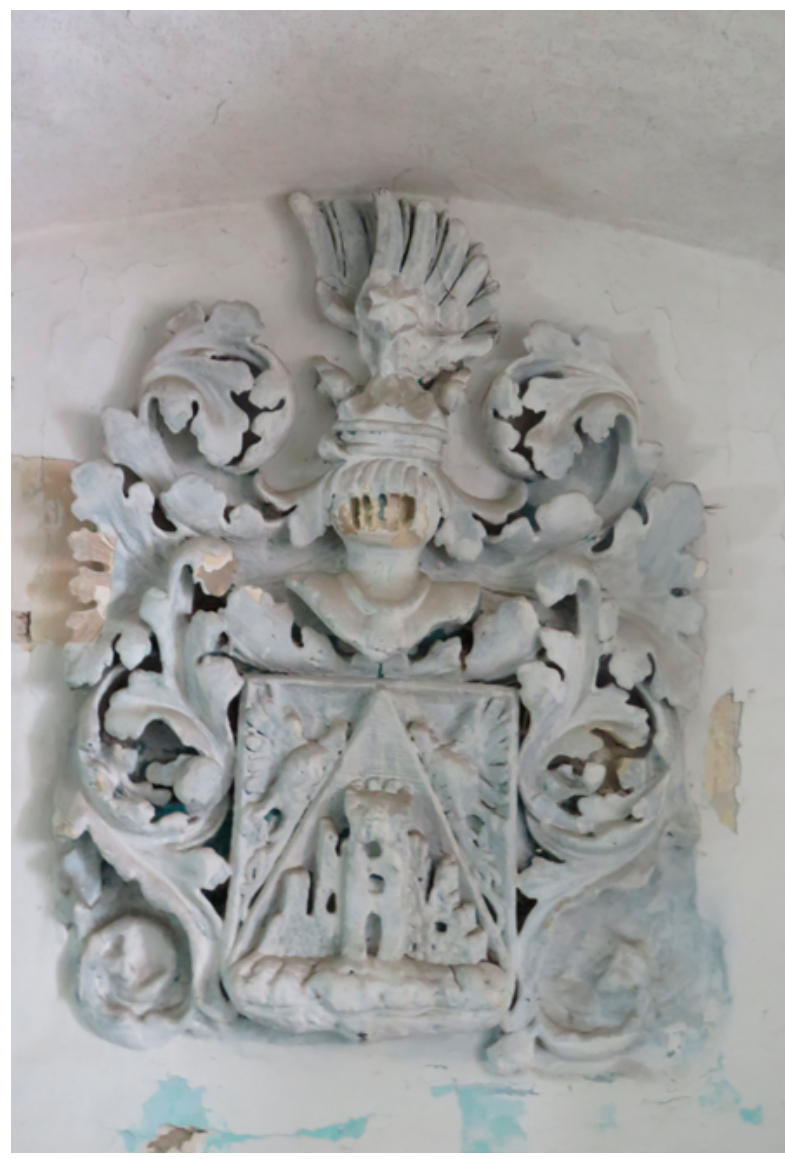

15. Grb obitelji Türk u dvorcu Kerestinec (snimka: V. Jakaša Borić, 2019.)

Coat of arms of the Türk family in Kerestinec castle (V. Jakaša Borić, 2019)

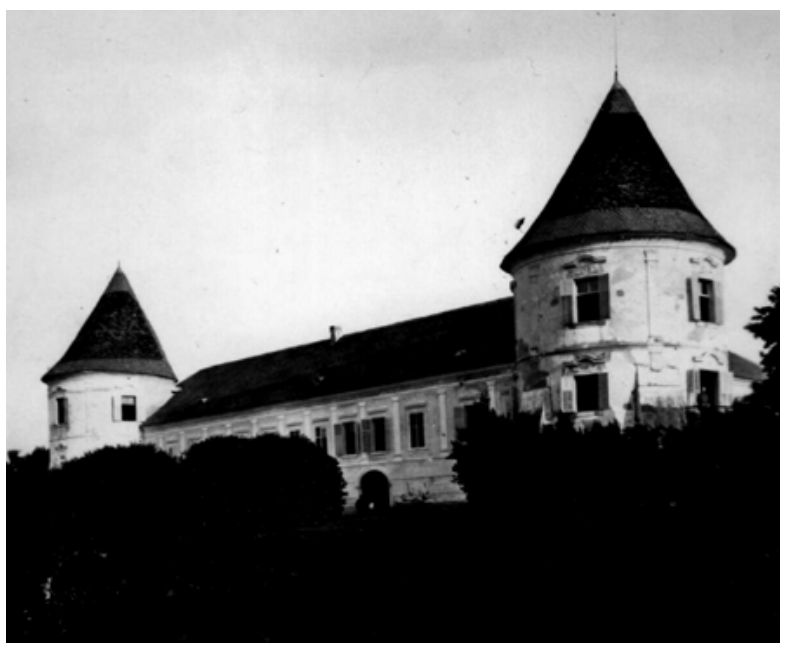

16. Dvorac Kerestinec prije Drugog svjetskog rata (MKM-FKB) Kerestinec castle before World War II (MKM-FKB)

poligonalna kapa, a unutar kojeg su drvene spiralne stepenice koje vode $u$ krovište, vjerojatno potječe iz istoga razdoblja.

U vremenu Prvog svjetskog rata dvorac je u vlasništvu R. Hafnera, a zatim industrijalca Vošnjaka, da bi ga 


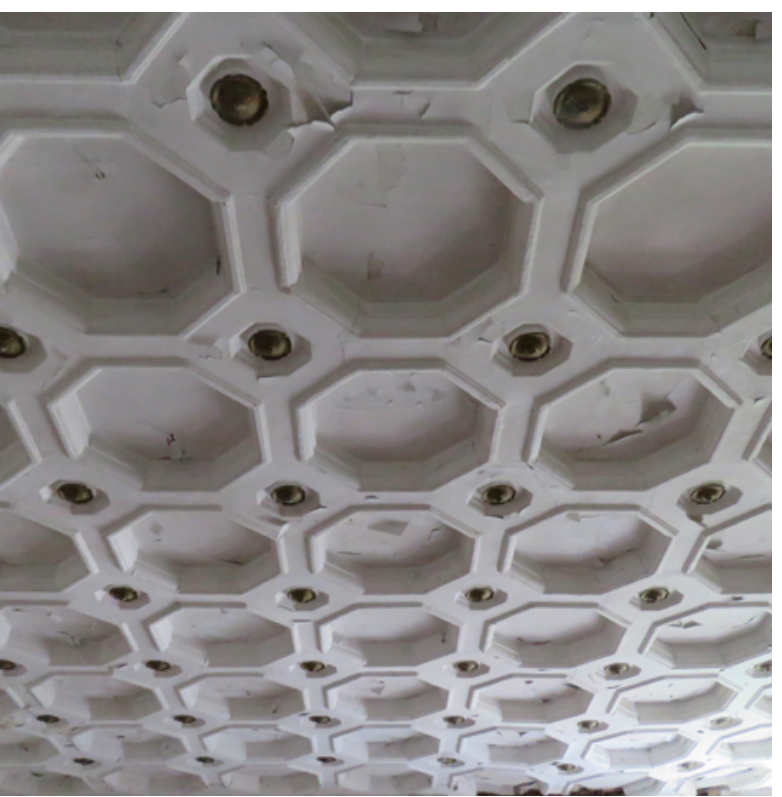

17. Kasetirani strop glavne dvorane zapadnog krila dvorca Kerestinec (snimka: V. Jakaša Borić, 2019.)

Coffered ceiling in the main hall of the west wing of Kerestinec castle (V. Jakaša Borić, 2019)

1922. kupio bivši hrvatski ban Mihalović, ujedno i posljednji privatni vlasnik. ${ }^{63}$ Tijekom Drugog svjetskog rata $u$ dvorcu je zloglasni ustaški logor, a nakon rata ulazi vojska (JNA) koja ostaje u njemu do 90-ih godina 20. stoljeća. Godine 1942./43. dograđeno je istočno jednokatno krilo koje volumenom, osnovnim prostornim rasporedom te raščlambom dvorišnog pročelja nizovima lučnih otvora polueliptoidne forme, ponavlja osnovni koncept baroknog sjevernog krila. ${ }^{64}$ Značajniji zahvat, koji poduzima vojska nakon Drugog svjetskog rata, izgradnja je prizemnice na južnoj strani dvorišta, na mjestu nekadašnjeg jednokatnog krila s kapelom, čime se zadržava zatvorena koncepcija cjeline. Iako su intervencije vojske bile „grube“ i neprimjerene, kao što je uostalom bila i sama namjena, zahvaljujući njihovoj prisutnosti i održavanju, dvorac je ipak ostao očuvan. Danas je bez namjene, u vlasništvu Grada Svete Nedelje.

\section{Zaključak}

Provedenim istraživanjima utvrđena je slojevitost kao važno obilježje i vrijednost dvorca koja predstavlja svjedočanstvo o njegovim mijenama i prilagodbi novim potrebama i načinu života. Unatoč brojnim pregradnjama, dvorac $u$ Kerestincu prezentira koncept renesansnog kaštela, odnosno ranog nizinskog dvorca $u$ formi zatvorene četverokutne građevine s ugaonim kulama i unutarnjim pravokutnim dvorištem. Od ovog su povijesnog sloja sačuvane dvije sjeverne kule i perimetralni zidovi dvaju krila (sjevernog i zapadnog), koji velikim dijelom potječu od starije kurije čije su građevne strukture bile integrirane u novu arhitektonsku cjelinu.
Osim građevne strukture i koncepcije renesansnog kaštela, dvorac baštini još dva značajna povijesna sloja. Barokizacijom su, naime, najvjerojatnije tijekom prve polovice 18. stoljeća, poduzeti veliki zahvati kako bi se dvorac osuvremenio i prilagodio načinu života koji se razvijao u skladu s novim okolnostima koje donosi prestanak turske opasnosti. Uz formiranje južnog krila s dvorskom kapelom Blažene Djevice Marije od Navještenja, dograđuju se arkadni hodnici kojima je uokvireno pačetvorinasto dvorište, pregrađeno je zapadno, a posebice sjeverno krilo kojem se ugrađuje novo trokrako stubište. Raskošno se oprema drugi stambeni kat sjevernog i zapadnog krila, o čemu svjedoči opis dvorca iz 1847. godine. Navedenim se intervencijama, međutim, nije postigla barokna sistematičnost jer je ulazna veža s glavnim portalom ostala na ekscentričnoj poziciji. Asimetrično je smještena i glavna dvorana na drugom katu sjevernog krila kao i kapela u okviru južnoga krila, čijom je izgradnjom cjelina zadržala zatvoreni karakter. Izostanak osovinske organizacije, kao i povezivanja dvorca s okolnim prostorom, bitnih tema zrelobarokne profane arhitekture koje će $u$ hrvatskoj rezidencijalnoj arhitekturi biti prvi puta ostvarene 40 -ih godina 18 . stoljeća, govori u prilog ranije navedenoj pretpostavci da se ovi barokizacijski zahvati odvijaju tijekom prve trećine 18. stoljeća. ${ }^{65}$

Obrambeni karakter dvorca potisnut je prilagodbom kula stambenim potrebama i uvođenjem pročeljne barokne plastike. Kule, naime, kao simboli davnih herojskih vremena, u funkciji "amblemskog motiva” ostaju očuvane, dok im se interijeri prenamjenjuju raskošnim uređenjem i rastvaranjem prozora s pogledom na perivoj. ${ }^{66}$ Ovaj se proces događa na mnogim dvorcima kontinentalne Hrvatske, kao na primjer na dvorcu Orehovečki u Gornjoj Rijeci ${ }^{67}$ i dvorcu Kulmer u Cerniku, ${ }^{68}$ a sklonost slikovitoj sceničnosti koja nosi konotacije snage i autoriteta, dokazuju i barokni dvorci izgrađeni u 18. stoljeću s ugaonim kulama (dvorci u Lužnici, Brezovici i Popovači). ${ }^{69}$ Posljednji je barokizacijski zahvat na dvorcu Erdödy bila obnova glavnog sjevernog pročelja i dviju sjevernih kula, uvođenjem barokne arhitektonske plastike kojom se ovaj dio povezuje $u$ cjelinu i naglašava kao reprezentativni $u$ odnosu na preostali dio dvorca. S obzirom na koncept $\mathrm{s}$ rustikom u prizemlju i pilastrima ritmiziranim katnim plohama te arhitektonskom plastikom $u$ vidu rastvorenih školjki i razgibanih nadstrešnica, zaključuje se da se posljednji barokizacijski zahvat vremenski može smjestiti oko sredine 18. stoljeća.

Iz vremena barokizacije, danas se zatječu arkadno rastvoreni hodnici sjevernog krila, prostorni raspored obiju etaža sjevernog krila uključujući pripadajuće svodne konstrukcije, kao i trokrako stubište s nišama. Barokna je plastika očuvana na pročeljima kula i na dvorišnom pročelju sjevernog krila, dok je na glavnom sjevernom pročelju, od baroknog sloja, sačuvan samo 
portal. Obnova s kraja 19. stoljeća, nakon velike štete nanesene potresom 1880. godine, donijela je značajne promjene u vidu uklanjanja južnih kula te drugoga kata sjevernog i zapadnog krila.

Navedeni povijesni slojevi koncentrirani su u okviru sjevernog i zapadnog krila s dvije ugaone kule. Ovi dijelovi predstavljaju svjedočanstvo arhitektonskog oblikovanja stambeno-obrambenog sklopa 16. stoljeća koji se tijekom narednih stoljeća razvija i dograđuje u skladu s povijesnim okolnostima i potrebama vlasnika, pri čemu renesansna koncepcija ostaje temeljna osobina cjeline.

\section{Bilješke}

1. LASZOWSKI, 1897, 399.

2. Ibidem.

3. LASZOWSKI, 1897, 400.

4. FELETAR, 2012, 59, 60, 103-105.

5. MILETIĆ, 2012, 165.

6. BOTICA, 8. lipnja 2017.

7. Građevna geneza dvorca, koju ovaj rad analizira i kontekstualizira, uključujue rezultate konzervatorsko-restauratorskih istražnih radova koje je izveo Vjekoslav Varšić, viši konzervator restaurator (V. Varšić, Izvješće, 2019.) pod konzervatorskim nadzorom i u suradnji s konzervatoricom i povjesničarkom umjetnosti dr.sc. Viki Jakaša Borić. Treba napomenuti da je sondiranje izvedeno na povijesnim dijelovima dvorca (sjeverno i zapadno krilo, te dvije kule), dok su slijed izgradnje i obilježja njegovih, danas nepostojećih dijelova, kao i transformacije cjeline kroz stoljeća, analizirani i interpretirani na temelju pisanih i grafičkih povijesnih izvora.

8. HR-HDA-387, Sudbeni stol Kraljevina Dalmacije, Hrvatske i Slavonije. Spis br. 8/1848. Predaja dobra Kerestinec sadašnjem zakupniku, grofu Aleksandru Erdődyju (Zagreb, 3. studenoga 1847.); prilog: inventar dobra sastavljen 18. i sljedećih dana mjeseca ožujka 1847., bez paginacije (prijepis dokumenta i prijevod pojedinih dijelova za potrebe istraživanja: Ladislav Dobrica, prof).

9. NAZg, KV, Arhiđakonat Katedrala, Župa Sveta Nedjelja, Protokol, 58/XIV, 1749., 53; 150/VI, 1852., 49.

10. MKM-FKB, I. Standl, iza potresa 1880., sign. II 15.424, II 15. 387, $57285,57286,57287$.

11. HR-HDA, DGU, k.o. Kerestinec, katastarski list, 1862.

12. Obitelj je poznata jer je u kratkom vremenskom razdoblju, unutar 20-ak godina, imala četiri zagrebačka kanonika od kojih je najpoznatiji, Petar Herešinec, bio biskup (1585. - 1587.), a bavio se i politikom te je bio predstavnik u Saboru u Požunu. Njegov stric Juraj Herešinec, kanonik od 1543. do 1571., izgradio je kuriju za zagrebačku prepozituru na Kaptolu br. 7. IVANČAN, 1925, 347, 391, 447; Šematizam Zagrebačke nadbiskupije, 1966, 34; DOBRONIĆ, 1988, 23.

13. ADAMČEK, 1980, 417; LASZOWSKI, 1897, 399; TOMEČAK, 1989, 7.

14. Zahvaljujem kolegi Dušku Čikari koji mi je skrenuo pažnju na ovu mogućnost, što je i potvrđeno provedenim sondiranjima.
Osim arhitektonske, sjeverno i zapadno krilo s kulama posjeduju visoku ambijentalnu, povijesnu i dokumentarnu vrijednost. Istočno krilo, izgrađeno tijekom Drugog svjetskog rata, volumenom i artikulacijom pročelja prilagođeno koncepciji i karakteru dvorca, smatra se ambijentalno uklopljenim, dok je prizemnica u ulozi južnoga krila beznačajna. U skladu s vrijednostima i značenjem navedenih dijelova dvorca, izrađene su konzervatorske smjernice za obnovu kojoj je cilj održiva prenamjena, odnosno afirmacija i očuvanje povijesnih slojeva uz uvođenje odgovarajuće funkcije.

Restauratorsko izvješće, Vjekoslav Varšić, ožujak, 2019., sonde: $1,6,3,8$.

15. Restauratorsko izvješće, Vjekoslav Varšić, ožujak, 2019., sonde: 28,5 .

16. O strukturi kurije 15. i 16. stoljeća vidi: VUČETIĆ, 2006, 422.

17. FELETAR, 2012, 60, 59; ADAMČEK, 1980, 249.

18. Petar I. Erdödy smatra se praocem hrvatske grane ove obitelji. Dobiva titulu baruna 1511. godine, zbog čega obiteljsko prezime Bakač mijenja u Erdödy de Monyórokerék. Njegov je sin Petar II. hrvatski ban od 1557. do 1567., a 1565. ga je, zbog vojnih uspjeha, car Maksimilijan nagradio nasljednim grofovskim naslovom. Sahranjen je u kapeli sv. Petra u jaskanskoj župnoj crkvi. Muška su djeca Petra II. bili Petar III. i Tomo II., a s njihovim potomstvom u četvrtom koljenu obitelj se dijeli u dvije grane, hrvatsku i ugarsku. Od 1587. je godine Petar III. bio veliki kapetan Žumberačke kapetanije, kapetan plaćenika i uskoka za Hrvatsku i Kranjsku, te zapovjednik uskoka i hrvatskih konjanika koji su branili Karlovac i Slunj. Godine 1599. napao je Turke u Slavoniji, zauzeo gradove Pakrac i Čaklovec te došao do Požege. lako sklon protestantizmu, odrekao ga se 1609. pod utjecajem kasnijeg zagrebačkog biskupa P. Domitrovića. HRVATSKI BIOGRAFSKI LEKSIKON, https://hbl. Izmk.hr/clanak.aspx?id=5717 (15.5.2021.); MANENICA, 1993, 15-32; BEDIĆ, 1996, 31-52; SZABO, 1995, 1-4.

19. KRČELIĆ, 1770, 459; HORVAT, 1964, 168; LASZOWSKI, 1897, 399.

20. Nizinski se kašteli grade kako bi se obranili posjedi i spasilo stanovništvo jer je često zaklon unutar kaštela bio jedini način za preživljavanje turskih pustošenja. Zidane kurije često postaju jezgrom budućih dvoraca koji se razvijaju dograđivanjem na te najstarije dijelove. ŽMEGAČ, 2008, 82.

21. FELETAR, 2012, 60.

22. Žitvanski mir nastupio je sklapanjem mirovnog ugovora između Habsburške Monarhije i Osmanskog Carstva 1606. godine. Ovim su mirom Hrvatskom kraljevstvu pripale utvrde Čazma, Petrinja, Moslavina, Gora i Hrastovica. ŠıŠıć, 2004, 306, 307.

23. TOMEČAK, 1989, 12.; Nadgrobna je ploča iz grobnice Petra III. Erdödyja ugrađena u južni lateralni zid župne crkve Presvetog Trojstva u Svetoj Nedelji nakon rušenja kapele sv. Petra, a tijekom izgradnje današnje barokne crkve u 18. stoljeću. Na ploči su ispisani stihovi na latinskom jeziku kojima se slavi Petrova hrabrost 
i istovremeno izražava tuga zbog njegove pogibije (prijevod: $d r$. sc. Šime Demo).

24. HRVATSKI BIOGRAFSKI LEKSIKON, https://hbl.Izmk.hr/ clanak.aspx?id=5717 (15.5.2021.); MANENICA, 1993, 95, 16; SZABO, 1995, 4.

25. Ibidem.

26. Planiraju se arheološka istraživanja kojima bi se dvije južne kule ubicirale i dokumentirale te moguće u arheološkom sloju u okviru projekta obnove dvorca, barem djelomice prezentirale. 27. HORVAT-LEVAJ, $2015,414$.

28. OBAD ŠĆITAROCI, 2005, 184-189; 58-61.

29. OBAD ŠĆITAROCI, 2005, 184-189; 280-283; HORVAT, 1975, 254; SZABO, 1912, 222-226.

30. Restauratorsko izvješće, Vjekoslav Varšić, ožujak, 2019., sonde 5, 28.

31. Pomicanjem istočnoga zida dobiveno je veće dvorište, što je bilo značajno jer se u kaštel moglo zakloniti više ljudi, a to je i bila njegova svrha - obrana posjeda i zaštita ljudi.

32. Možda je ova kula pripadala najranijem sloju kaštela iz vremena P. Herešinca. Usporedi: VUČETIĆ, 2006, 422.

33. HR-HDA-387, Sudbeni stol Kraljevina Dalmacije, Hrvatske i Slavonije. Spis br. 8/1848.

34. Današnji barokni portal polueliptoidne forme prati formu svoda veže koji istovremeno nastaje u 18. stoljeću. Nije poznato kako je izgledao prvotni renesansni portal, no treba napomenuti da su portali renesansnih kaštela imali polukružni zaključak, često upisan u pravokutnik, pa su dva gornja ugla ponekad ispunjena vegetabilnim dekorativnim elementima (npr. glavni portal dvorca Erdödy u Novim Dvorima Klenječkim, portal dvorca Erdödy u Jaski, portal dvorca Keglević u Gorici itd.). HORVAT-LEVAJ, 2015, 414. 35. ŠIŠIĆ, 2004, 331-334.

36. FELETAR, 2012, 60.

37. NAZg, KV, Arhiđakonat Katedrala, Župa Sveta Nedelja, Protokol 150/6, 1852., 42, (prijevod: dr.sc. Šime Demo). Dragocjen podatak o prestanku vlasništva obitelji Erdödy u Kerestincu donosi zapis vizitacije iz 1852. godine u vezi s preuzimanjem prava patronata nad župama koje spadaju pod Okić. Vizitator, naime, navodi da su kolatori nasljednici grofa Aleksandra njegovi sinovi Juraj i Ivan Nepomuk, međutim neizvjesno je tko će preuzeti patronat obzirom na to da iste godine sva imovina Kerestinca mora biti prodana sudskim putem.

38. Stubište je do danas djelomice očuvano s tim da su stube i podesti u dijelu koji vezuje prizemlje i kat, tijekom druge polovice 20. stoljeća betonirani. Gornji je dio stubišta, uklanjanjem drugoga kata, ostao u potkrovlju te je, zahvaljujući tome, usprkos oštećenjima, do danas fragmentarno očuvan u izvornom obliku. Riječ je o kamenim stubama profiliranih gazišta i podestima popločanim kvadratnim kamenim pločama manjeg formata. 39. Nalazi sondi u katnim prostorijama dokazuju da su prostorije iz ranije građevne faze bile zaključene grednicima. Naime, zidna žbuka koja se proteže ispod svodne konstrukcije, svjedoči o postojanju stropnog zaključka prostorije prije ugradnje svoda. Restauratorsko izvješće, Vjekoslav Varšić, ožujak, 2019., sonde 23, 24.
40. Vladimir Marković, analizirajući arhitektonsko oblikovanje dvoraca Hrvatskog zagorja, zaključuje da je bačvasti svod zasječen susvodnicama lomljenih bridova najčešći u drugoj polovici 18. stoljeća. MARKOVIĆ, 1995, 83.

41. Na vojnoj topografskoj karti iz 8o-ih godina 18. stoljeća prikazan je već formirani perivoj sjeverno od dvorca, a nešto zapadnije nalazi se gospodarska zona. (https://maps.arcanum.com). 42. Fotografija I. Standla s pogledom na dvorišno pročelje istočnog krila svjedočanstvo je njegove artikulacije. Naime, samo je prizemna zona bila arkadno rastvorena, dok su hodnici na prvom katu rastvoreni manjim četvrtastim prozorima, a na drugom većima, pravokutne forme.

43. Prema opisu iz 1847. godine, hodnik drugog kata zapadnog krila imao je strop od dasaka koji nose okrugli stupovi, dok je onaj na sjevernom dijelu pod svodom koji podržavaju četvrtasti stupovi. 44. HR-HDA-387, Sudbeni stol Kraljevina Dalmacije, Hrvatske i Slavonije. Spis br. 8/1848.

45. HR-HDA-387, Sudbeni stol Kraljevina Dalmacije, Hrvatske i Slavonije. Spis br. 8/1848.: “ (...) Cubile Tafelzimmer cum porta dupplicata ex ligno quercino bona, cum seratura et clavi. Fornaces duae usuabiles. Pavimentum stakatur rupturas in se habens. Tabulatum tabulis ligneis quadratis quercinis crucibus intermixtum habet, quatuor columnis marmorisatis insistens. Fenestrae quinque commodae. Valvae vero destructae. Ex quo per portam affabre factam inauratam dupplicatam seratura absque clavi provisam venitur ad cubile Sitzimmer." (prijepis: Ladislav Dobrica, prof).

46. HR-HDA-387, Sudbeni stol Kraljevina Dalmacije, Hrvatske i Slavonije. Spis br. 8/1848.: "Pavimentum stakatur ruptum et vitiatum. Tabulatum parquet quadratis albonigris provisum. Parietes tapetibus papyraceis vitiatis obducti. Fornax affabre constructa. Statuam superne habens in bono statu. Speculum immuratum habens. Fenestrae duae mediocres." (prijepis: Ladislav Dobrica, prof).

47. HR-HDA-387, Sudbeni stol Kraljevina Dalmacije, Hrvatske i Slavonije. Spis br. 8/1848.: "Valvae reparationem exposcentes, ex quo sub arcu devenitur ad turrim camino provisam, cui statua Ceres insistit. Pavimentum stakatur rupturas habens. Tabulae parquettae quadratae albo-nigras tabulas. Parietes marmorisati. Fenestrae tres internae in bono statu (...) Ex cubili Sitzimmer devenitur ad cubile per portam dupplicatam affabre factam inauratam seratura absque clavi provisa. Pavimentum in aliqua parte rupturas habens. Tabulatum parquettam variegentem figuram praeseferens. Parietes papyraceis tapetibus laceris obducti. Fornax ex albis tabulis in superiore parte quatuor columnas habens in statu bono. Fenestrae duae internae in statu commodo. Valvae reparatione indignae. Specula immurata duo." (prijepis: Ladislav Dobrica, prof).

48. NSK, Zbirka zemljovida i atlasa, Mappa Dioecesis Zagrabiensis, bakrorez, 9 listova, 1822.-1825.

49. NAZg, KV, Arhiđakonat Katedrala, Župa Sveta Nedjelja, Protokol, 58/XIV, 1749., 53; 150/VI, 1852., 49. Ladislav II (1693.1747.), sin Aleksandra III. bio je kapetan Petrinje i major u Banskoj krajini. Godine 1740. darovnicom Karla VI. stekao je posjede obitelji Pethő de Gerse u Varaždinskoj županiji. Na stečenim je posjedima gradio dvorac u Gornjem Cerju te pregradio dvorac u Ivancu (1744). Obnavljao je i kaštel Jastrebarsko (1741). 
HRVATSKI BIOGRAFSKI LEKSIKON, https://hbl.lzmk.hr/clanak. aspx?id=5717. (15.5.2021.).

50. HR-HDA-387, Sudbeni stol Kraljevina Dalmacije, Hrvatske i Slavonije. Spis br. 8/1848.

51. MARKOVIĆ, 1995, 67.

52. Restauratorsko izvješće, Vjekoslav Varšić, ožujak, 2019., sonde: 9, 10, 11, 12.

53. PUHMAJER, 2016, 214. Djelovanjem štajerskih graditelja na području Hrvatske utjecaji se brzo šire, a među prve i vrlo značajne primjere spadaju palača Zrinski u Zagrebu i Prašinski Sermage u Varaždinu koje nastaju 80-ih ili najkasnije sredinom 90 -ih godina 17. stoljeća. Dekoracija pročelja motivima slikanih kvadriloba javlja se ranije, tijekom 17. stoljeća.

54. Vidi bilj. 37.

55. HR-HDA, DGU, k.o. Kerestinec., 1862., popis čestica (Parzellen protocol) uz katastarski list.

56. Uspoređena vojna topografska karta civilne Hrvatske iz 1783 .1784. (https://maps.arcanum.com/en/map/europe-18centuryfirstsurvey/?layers) i katastarski list iz 1862. (HR-HDA, DGU, k.o. Kerestinec).

\section{Izvori}

HR-HDA-387 Hrvatski državni arhiv, Sudbeni stol Kraljevina Dalmacije, Hrvatske i Slavonije

HR-HDA Hrvatski državni arhiv, Državna geodetska uprava

NAZg KV Nadbiskupijski arhiv Zagreb,

kanonske vizitacije, Arhiđakonat Katedrala, Župa Sveta Nedelja,
57. U tekstu Emilija Laszowskog iz 1897. zabilježeno je da je dvorac u vlasništvu Aurela Türka. LASZOWSKI, 1897, 400.

58. https://www.geni.com/people/Franjo-Aurel-T\%C3\%BCrkEdler-von-Karlovacgrad (25.4.2021.).

59. MKM-FKB, moguće autorstvo samoborskog ljekarnika i fotografa amatera Mirka Kleščića, između 1900. i 1930.

60. Restauratorsko izvješće, Vjekoslav Varšić, ožujak, 2019., sonda: 1.

61. Restauratorsko izvješće, Vjekoslav Varšić, ožujak, 2019., sonde: $1,2$.

62. Kaljeva peć iz ovoga razdoblja još je 90 -ih godina 20. stoljeća bila sačuvana, no u međuvremenu je odnesena iz dvorca.

63. HORVAT, HABUNEK-MORAVAC, ALEKSIĆ, 1970, 45.

64. Ibidem.

65. HORVAT-LEVAJ, 2015, 565.

66. MARKOVIĆ, 1995, 114.

67. VISIN, JAKAŠA BORIĆ, 2013, 228.

68. PUHMAJER, 2020, 217.

69. MARKOVIĆ, 1995, 112-114.

\section{Literatura}

JOSIP ADAMČEK, Agrarni odnosi u Hrvatskoj od sredine XV do kraja XVII stoljeća, Zagreb, 1980.

MARKO BEDIĆ, Velikaška obitelj Erdödy-uspon i pad, Kaj, XXIX, 3 (1996.), 31-52

DUBRAVKA BOTICA, U prilog inicijativi za obnovu dvorca Erdödy u Kerestincu, Neizvjesna budućnost dvoraca, u: Vijenac, 607, 8. lipnja 2017.

LELJA DOBRONIĆ, Zagrebački Kaptol i Gornji grad nekad i danas, Zagreb, 1988.

DRAGUTIN FELETAR, Grad Sueta Nedelja na zapadnim vratima Zagreba, Samobor, 2012.

ANĐELA HORVAT, Između gotike i baroka: umjetnost kontinentalnog dijela Hrvatske od oko 1500. do oko 1700., Zagreb, 1975.

ANĐELA HORVAT, Kerestinec, ELU, sv. III., 1964.,168

ANDELA HORVAT, ŠTEFICA HABUNEK-MORAVAC; NADA ALEKSIĆ, Dvorci i kurije sjeverne Hrvatske, Republički zavod za zaštitu spomenika kulture, 1970.

KATARINA HORVAT-LEVAJ, Barokna arhitektura, Zagreb, 2015. LJUBO IVANČAN, Podaci o zagrebačkim kanonicima, 1925. BALTAZAR ADAM KRČELIĆ, Prethodne napomene o kraljevstvima Dalmacije, Hrvatske i Slavonije (De Regnis Dalmatiae, Croatiae, Slavoniae notitiae praeliminares), 1770.

KREŠIMIR TOMEČAK, Župa Sveta Nedelja, povijesni prikaz do oko 1880. godine, tipkopis, Zagreb, 1989.

NSK Nacionalna sveučilišna knjižnica, Zbirka zemljovida i atlasa MKM-FKB Ministarstvo kulture i medija, Zbirka fotografske dokumentacije

EMILIJ LASZOWSKI, Okić-grad, Prosvjeta, Zagreb, 1897. LOVRO MANENICA, Grofovi Erdödy: u ozračju hrvatske povijesti, Novi Marof, 1993.

VLADIMIR MARKOVIĆ, Barokni dvorci Hrvatskog zagorja, Zagreb, 1995.

DRAGO MILETIĆ, Plemićki gradovi kontinentalne Hrvatske, Zagreb, 2012.

BOJANA OBAD ŠĆITAROCI, MLADEN OBAD ŠĆITAROCI, Dvorci i perivoji Slavonije - od Zagreba do lloka, Zagreb, 1998.

MLADEN OBAD ŠĆITAROCI, Dvorci i perivoji Hrvatskog zagorja, Zagreb, 2005.

PETAR PUHMAJER, Žbukani i naslikani medaljoni - prilog razvoju pročelja 17. i 18. stoljeća u kontinentalnoj Hrvatskoj, Portal, 7 (2016.), 209-228

PETAR PUHMAJER, Dvorac Cernik - kontinuitet i mijene predturskog nasljeđa u barokno doba, Radovi IPU, 43 (2020.), 211-220 GJURO SZABO, Spomenici kotara Klanjec i Pregrada, Vjesnik HAD-a, sv. XII (1912.)

AGNEZA SZABO, Hrvatska grana grofova Erdödy, Matica: časopis Hrvatske matice iseljenika , 45 (1995.), 1-4

FERDO ŠIŠIĆ, Povijest Hrvata, Pregled povijesti hrvatskog naroda 1526. - 1918., II. dio, Split, 2004. 
MIRJANA VISIN, VIKI JAKAŠA BORIĆ, Dvorac Gornja Rijeka obnova i prenamjena, u: Zbornik II kongresa hrvatskih povjesničara umjetnosti, Zagreb, 2013., 227-233

RATKO VUČETIĆ, Prilog razvoju i tipologiji kurija u kontinentalnoj Hrvatskoj, u: Dvorci i ljetnikovci kulturno naslijeđe kao pokretač gospodarskog razvoja, ur. Mladen Obad Šćitaroci, Nikša Božić, Zagreb: Sveučilište u Zagrebu - Arhitektonski fakultet, 2006., 415-425
ANDREJ ŽMEGAČ, Feudalna profana arhitektura - vlastelinski gradovi (burgovi), dvorci, kurije, u: Umjetnička topografija Hrvatske, Krapinsko-zagorska županija, ur. Ivanka Reberski, Zagreb, 2008., 81-86

Šematizam Zagrebačke nadbiskupije, 1966.

\section{Summary}

Viki Jakaša Borić

\section{ERDÖDY CASTLE IN KERESTINEC: $16^{\mathrm{TH}}$-CENTURY RENAISSANCE CASTLE AND ITS PHASES}

The paper presents the history of construction of the Erdödy castle in Kerestinec, on the basis of field and archival research. The different layers and changes to the castle are also analysed, from the original construction, attributed to the manor house of Petar Herešinec, and the lowland castle with four corner towers, built by Petar III Erdödy during the 1670s and 1680s, through the extensive Baroque interventions during the $18^{\text {th }}$ century, to reconstruction and neo-style renovations after the great earthquake of 1880 , and the changes during the $20^{\text {th }}$ century that shaped the current layout of the castle. Despite numerous additions and alterations, the castle in Kerestinec presents the concept of a Renaissance castle, i.e. an early lowland castle in the form of a closed square building with corner towers and a rectangular inner courtyard. The two northern towers and the perimeter walls of two wings (northern and western), remains of the older manor house since its building structures were integrated into the new architectural complex, have been preserved from this phase.

In addition to the building structure and Renaissance castle concept, the castle has two other significant historical layers. During the first half of the $18^{\text {th }}$ century, major Baroque interventions were most likely added to modernize the castle and adapt it to the new way of life when there was no more threat of Ottoman attacks. The south wing with the court chapel was built at the same time, along with arcaded corridors that framed the quadrangular courtyard, rebuilding the west and north wings, and adding a new three-storey staircase to the latter. The second residential floor of the north and west wings was luxuriously furnished (confirmed by a description of the castle from 1847). These interventions, however, did not achieve Baroque systematicity, because the entrance tower with the main portal remained in an eccentric position. The main hall on the second floor of the north wing is asymmetrically located, as is the chapel of the Blessed Virgin Mary of the Annunciation within the south wing. The construction of the chapel preserved the closed character of the wing. Absence of the axis, as well as connecting the castle with the surrounding area (important themes of the mature Baroque secular architecture that appeared in Croatian residential architecture for the first time in the 1840s), supports the earlier assumption that these Baroque interventions were carried out during the first third of the $18^{\text {th }}$ century.

The defensive character of the castle was suppressed by adapting the towers to residential needs and introducing Baroque sculptural decoration on the façade. The towers, as symbols of past heroic times, remain preserved as an 'emblematic motif', while their interiors have been repurposed with lavish decoration and the opening up of windows that overlook the park. Many castles in continental Croatia went through this process, such as the Orehovečki castle in Gornja Rijeka and the Kulmer castle in Cernik, and a penchant for pictorial staging with connotations of strength and authority can be seen in Baroque castles with corner towers from the $18^{\text {th }}$ century: castles in Lužnica, Brezovica and Popovača. The last Baroque intervention on Erdödy castle was the restoration of the main northern façade and two northern towers by introducing Baroque architectural sculptures, integrating and highlighting this part of the castle as representative. Considering the concept with rustic spaces on the ground floor and rhythmic upper floors with pilasters, and architectural sculptures in the form of open shells and varied canopies, it can be concluded that the last Baroque project can be dated to the mid-18 century. Elements from the Baroque period include the arcaded corridors of the north wing (Fig. 17), layout of both floors of the north wing including arched ceilings, and the three-storey staircase with niches. Baroque sculptures on the facades of the towers, as well as on the courtyard façade of the north wing, have been preserved, but the portal is the only Baroque element that has been preserved on the main north façade.

Restoration at the end of the $19^{\text {th }}$ century after extensive damage caused by the 1880 earthquake brought significant changes: the southern towers and the second floor of the castle were completely removed. Providing evidence of the restoration on the present-day castle are the design of the north façade (Fig. 8) and the layout of the first floor of the west wing, including the ceiling cassette 
structures (main hall and circular hall in the north-west tower). The courtyard façade of the west wing, with a polygonal tower (oriel window) with a wooden spiral staircase leading from the first floor to the attic, also probably date from this period. The east wing, with the volume and articulation of the façade adapted to the existing condition, was built during World War II, and a brick ground floor was recently erected where the south wing used to be. In accordance with the values and significance of the above-mentioned parts of the castle, conservation guidelines have been developed. Their goal is sustainable conversion: affirmation and preservation of historical layers with the introduction of an appropriate function.

KEYwORDS: Kerestinec, $16^{\text {th }}, 18^{\text {th }}$ and $19^{\text {th }}$ centuries, castle, Renaissance castle, Baroque, neo-style renovation, Herešinec family, Erdödy family, Pallavicini family, Türk family 
